\title{
Palaeoecology and palaeoenvironments of the Middle Jurassic to lowermost Cretaceous Agardhfiellet Formation (Bathonian-Ryazanian), Spitsbergen, Svalbard
}

\author{
Maayke J. Koevoets', Øyvind Hammer' \& Crispin T.S. Little ${ }^{2}$ \\ ${ }^{1}$ Natural History Museum, University of Oslo, P.O. Box 1172 Blindern, 0318 Oslo, Norway. \\ ${ }^{2}$ School of Earth and Environment, University of Leeds, Leeds LS2 9JT, United Kingdom. \\ E-mail corresponding author (Maayke J. Koevoets):m.j.koevoets@nhm.uio.no
}

We describe the invertebrate assemblages in the Middle Jurassic to lowermost Cretaceous of the Agardhfjellet Formation present in the DH2 rock-core material of Central Spitsbergen (Svalbard). Previous studies of the Agardhfjellet Formation do not accurately reflect the distribution of invertebrates throughout the unit as they were limited to sampling discontinuous intervals at outcrop. The rock-core material shows the benthic bivalve fauna to reflect dysoxic, but not anoxic environments for the Oxfordian-Lower Kimmeridgian interval with sporadic monospecific assemblages of epifaunal bivalves, and more favourable conditions in the Volgian, with major increases in abundance and diversity of Hartwellia sp. assemblages. Overall, the new information from cores shows that abundance, diversity and stratigraphic continuity of the fossil record in the Upper Jurassic of Spitsbergen are considerably higher than indicated in outcrop studies. The inferred life positions and feeding habits of the benthic fauna refine our understanding of the depositional environments of the Agardhfjellet Formation. The pattern of occurrence of the bivalve genera is correlated with published studies of Arctic localities in East Greenland and northern Siberia and shows similarities in palaeoecology with the former but not the latter. Ammonite biostratigraphy is used as a tool to date bivalve assemblage overturning events to help identify similar changes in other sections.

Keywords: Black shale, core, biofacies, biodiversity, bivalves, ammonites

Received 30. September 2018 / Accepted 22. January 2019 / Published online 20. June 2019

\section{Introduction}

The Middle Jurassic to lowermost Cretaceous Agardhfjellet Formation of Spitsbergen is dominated by organic-rich shales and may be considered as a partial time equivalent of the Kimmeridge Clay Formation of Great Britain, the Draupne Formation of the Norwegian Sea, and the Hekkingen Formation of the Barents Sea, all of which are important petroleum source rocks. The Agardhfjellet Formation has been the focus of many previous palaeontological studies. These include papers on vertebrates (Ginsburg \& Janvier, 1974; Hurum et al., 2012; Knutsen et al., 2012; Roberts et al., 2014, 2017; Delsett et al., 2015, 2017), palynology and microfossils (Bjærke, 1980; Århus, 1988; Nagy et al., 1990, 2009; Nagy
\& Basov, 1998; Hjálmarsdóttir et al., 2012; Nakrem \& Kiessling, 2012; Dalseg et al., 2016), ammonites (Kopik \& Wierzbowski, 1988; Wierzbowski, 1989; Rogov, 2010, 2014; Wierzbowski et al., 2011), echinoderms (Rousseau \& Nakrem, 2012) and hydrocarbon seep fauna (Holmer \& Nakrem, 2012; Hryniewicz et al., 2014; Sandy et al., 2014). In contrast, the non-seep bivalve fauna of the Agardhfjellet Formation has been less well studied. Birkenmajer et al. (1982) collected bivalve specimens from Myklegardfjellet and Agardhfjellet, on the east coast of Spitsbergen, from the harder lithologies of the formation (e.g., sandstones, siltstones, siderite layers and carbonate concretions). These rock types are volumetrically subordinate to black shales in the Agardhfjellet Formation. In the field, the black shales have been subjected to repeated frost wedging, breaking them into small pieces; consequently,

Koevoets, M.J., Hammer, Ø. \& Little, C.T.S. 2019: Palaeoecology and palaeoenvironments of the Middle Jurassic to lowermost Cretaceous Agardh-fjellet Formation (Bathonian-Ryazanian), Spitsbergen, Svalbard. Norwegian Journal of Geology 99, 17-40. https://dx.doi.org/10.17850/ njg99-1-02. 
invertebrate fossils are hard to find at outcrop in the majority of the formation.

In this study, we provide data on bivalve and ammonite faunas, as well as other invertebrate fossils, from the Agardhfjellet Formation in rock cores and from field studies in Central Spitsbergen between 2013 and 2016. The rock cores proved to be an excellent source of invertebrate fossils and revealed a far richer fauna than previously assumed. We use this invertebrate fauna, together with previous geochemical and sedimentological studies, to provide an integrated palaeoecological and palaeoenvironmental analysis of the Agardhfjellet Formation, and, using ammonites for correlation, compare this to other High Boreal sections in East Greenland and northern Siberia.

\section{Geological Background}

The Agardhfjellet Formation is 250 metres thick at the Janusfjellet section (Fig. 1) and consists of four members: the Oppdalen Member (Bathonian to Oxfordian), the Lardyfjellet Member (Lower Kimmeridgian), the Oppdalssåta Member (Upper Kimmeridgian) and the Slottsmøya Member (Volgian to Ryazanian), with considerable lateral thickness variations between the members (Fig. 2). The succession consists mainly of dark, organic-rich shales (TOC between 2 and 12\%; Koevoets et al. (2016)), interbedded with siltstones, sandstones and concretionary carbonates (Dypvik, 1984; Dypvik et al., 1991b; Koevoets et al., 2018). The sediments were deposited in a shallow-marine, dysoxic environment, where there was periodic oxygenation, according to Koevoets et al. (2018) and Collignon \& Hammer (2012), based on major and trace element analysis. The only true anoxic interval in the Agardhfjellet Formation is situated in the Lardyfjellet Member, where shales are finely laminated and with little or no benthic invertebrate fauna or bioturbation.

The Oppdalen Member (Bathonian-Lower Oxfordian) shows a fining-upward trend, associated with transgression and the retrogradation of the coastline (Koevoets et al., 2018). The Lardyfiellet Member (Kimmeridgian), with organic-rich black shales at the base, coarsens upward into the base of the Oppdalssåta Member, ending with tabular sandstone bodies. These sandstone bodies belong to the distal part of a delta front (Koevoets et al., 2018) or sand bars (Dypvik et al., 1991b). The Oppdalssåta Member comprises three smaller coarsening-upward units, grading from shales at their bases to fine-grained sandstones (Upper Kimmeridgian-?Volgian), capped with glauconitic, sideritic and carbonate-cemented beds containing wood fragments, belemnites, gastropods, bivalves and ammonites. Koevoets et al. (2018) assigned these coarsening-upward units to a prolonged regressional

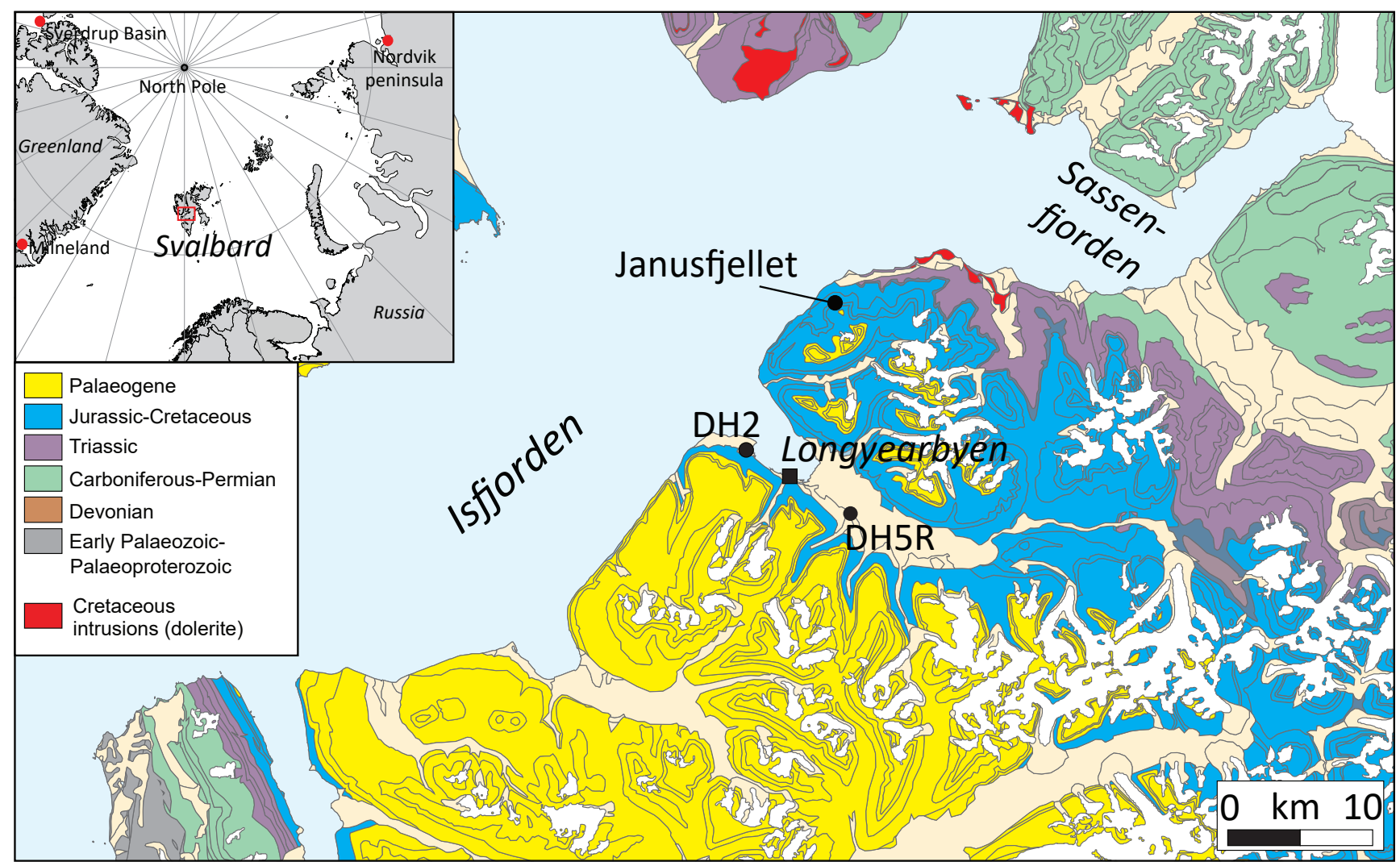

Figure 1. Geological map of the Isfjorden area in Central Spitsbergen (modified from Koevoets et al., 2018). 


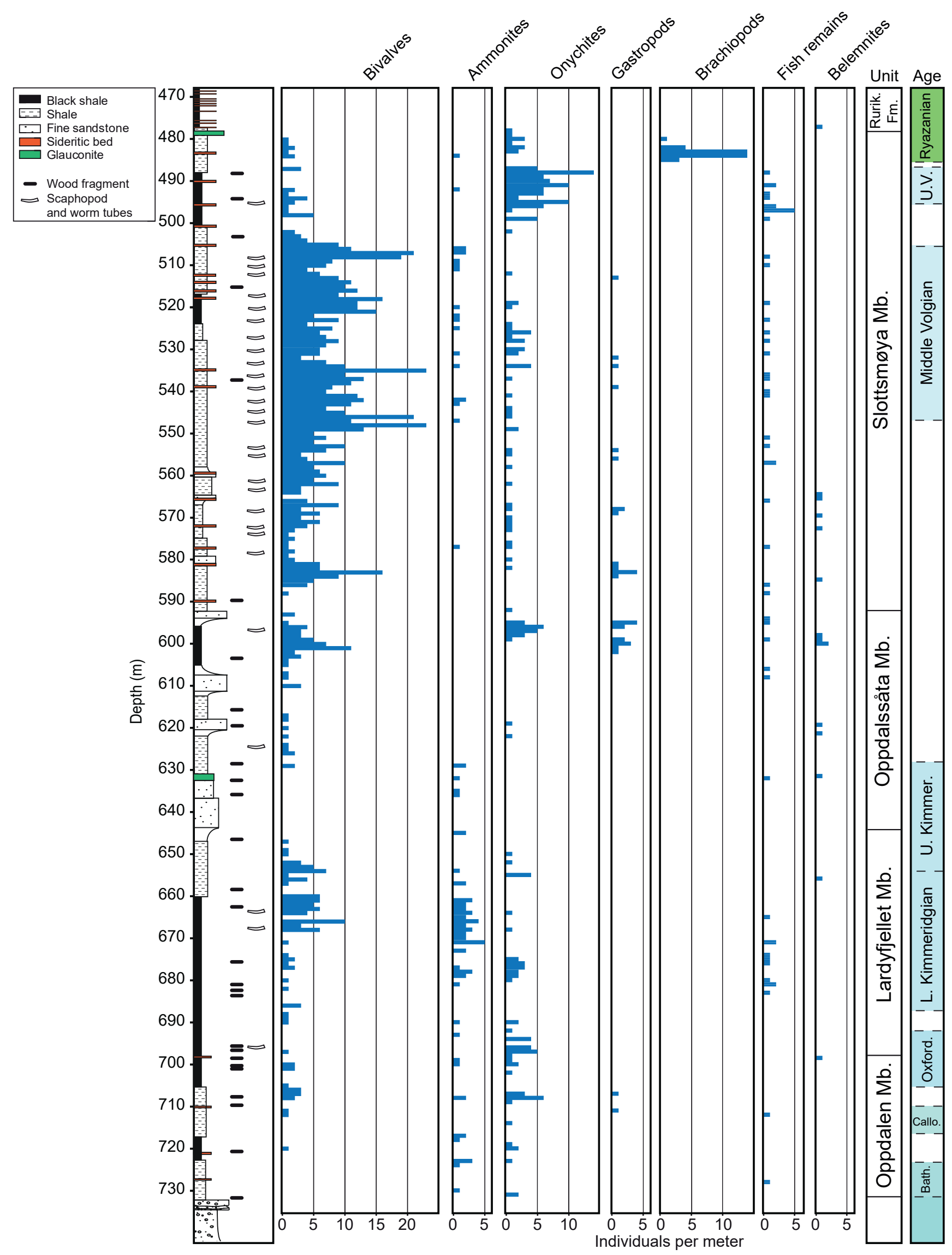


phase. A gradual transgression followed in the Slottsmøya Member, which consists mainly of shales and siltstones, interbedded with sideritic beds and dolomite concretions (Dypvik, 1984; Koevoets et al., 2018). The last of the coarsening-upward sequences in the Volgian show more distal finer-grained deposits (Koevoets et al., 2018). The Late Bathonian-Early Oxfordian transgressional phase, Early Kimmeridgian-Early Volgian regressional phase, and early Volgian to Ryazanian transgressional phase are also recognised in East Greenland (Surlyk, 1991) and the Sverdrup Basin (Embry, 1993).

\section{Materials and methods}

In November-December of 2007, the DH2 rock core was drilled as part of the UNIS CO2 LAB project, researching the feasibility of $\mathrm{CO} 2$ storage on Spitsbergen in the Triassic-Lower Jurassic sandstones (Ogata et al., 2014; Sand et al., 2014). The complete 250 metre-thick, Middle Jurassic-Lowermost Cretaceous Agardhfjellet Formation sequence was fully recovered in the well. The well is located at Hotellneset, on the western shore of Adventfjorden, along the Longyearbyen airport road, Spitsbergen (Braathen et al., 2012) (Fig. 1). Drilling was performed with an ONRAM 1400 rig belonging to Store Norske Spitsbergen Kulkompani (SNSK), which allowed for continuous full-coring by a wireline system using telescope drilling (Braathen et al., 2012). The core is kept in wooden, metre-long boxes each containing up to 5 metres of core-material and stored in a dry, cool facility in Endalen, Spitsbergen.

Complete and fragmentary macrofossils were noted whenever they occurred on core breakage surfaces, the number of which was variable depending on lithology. Some lithologies formed continuous metres of core and were broken at up to ten levels per metre to increase fossil specimen recovery. The main fossil groups are ammonites, belemnites, bivalves, brachiopods, gastropods, onychites (cephalopod hooks) and teleost remains. The specimens of each group per metre of core-section were counted (Fig. 2). Other macrofossils, such as scaphopods and wood fragments, were also noted in the stratigraphic column (Fig. 2).

The fossils were identified to genus level, but species level identification proved difficult, because the majority of the fossils were preserved as moulds, mostly external. Those ammonite, brachiopod, bivalve and gastropod moulds that were identifiable were collected, and then prepared, where possible, with a fine pneumatic drill using a Zeiss Stereomicroscope SV8. The fossils were photographed using a Canon 550D camera after coating them in a thin layer of ammonium-chloride to increase contrast. The specimens were stored individually in cardboard boxes and given numbers for the Palaeontology department of the Museum of Natural History in Oslo (PMO). They were identified by comparison with other Boreal/Subboreal invertebrate fossils (Imlay, 1953; Gerasimov, 1955; Jeletzky, 1966; Zakharov, 1966, 1987; Mesezhnikov, 1972, 1984; Duff, 1978; Fürsich, 1982; Callomon \& Birkelund, 1982; Kelly, 1984; Birkelund \& Callomon, 1985; Kopik \& Wierzbowski, 1988; Wierzbowski, 1989; Birkenmajer \& Wierzbowski, 1991; Callomon, 1993; Zakharov \& Rogov, 2008; Rogov \& Zakharov, 2009; Rogov, 2010, 2014; Holmer \& Nakrem, 2012; Hryniewicz et al., 2014, 2015; Koevoets et al., 2016).

Palaeoecological information on the identified invertebrate fauna, mainly bivalves, was obtained using the publications of Stanley (1970) and Cox et al. (1969), and earlier works on invertebrate fauna across the Boreal and Sub-boreal realms of the Upper Jurassic by Fürsich (1982, 1984), Birkenmajer et al.(1982), Kelly (1984), Kopik \& Wierzbowski (1988), Wignall (1990) and Hryniewicz et al. (2014). Of particular interest in this study were the life positions (infaunal, semi-infaunal or epifaunal) and feeding habits (filter or deposit feeding). Figure 3 shows a compilation of palaeoecological data for each species of bivalve throughout the stratigraphy.

Selected pieces of core were imaged for cryptic bioturbation using a Nikon Metrology XT H 225 ST microfocus CT scanner at the Natural History Museum, University of Oslo, at $200 \mathrm{kV}, 0.5 \mathrm{~s}$ exposure, 3000 rotations, $0.25 \mathrm{~mm}$ tin filter.

\section{Palaeoecological and palaeoenviron- mental reconstructions}

\section{Oppdalen Member}

The Oppdalen Member (Bathonian-Lower Oxfordian) is the least fossiliferous interval of the Agardhfjellet Formation (Figs. $3 \& 4$ ). Consisting mainly of pyrite-rich, silty shales and muddy siltstones as part of a transgressive sequence ending in laminated black shale, it is believed to represent an outer-shelf deposit (Koevoets et al., 2018). Figure 3 shows low faunal abundances for the Oppdalen Member. Nektic fossils, such as the ammonites Cadoceras sp. (Fig. 5G) and Kepplerites (Seymourites) aff. svalbardensis and onychites, are more common throughout the member than benthic fossils. Onychites become even more abundant towards the top of the member. Bivalves and gastropods become somewhat more numerous in the Lower Oxfordian, but the bivalve fauna consists only of Grammatodon cf. pictum (Fig. 6H, I) (Milashevich, 1881; Gerasimov, 1955) and Mesosaccella sp. (Fig. 7E) (Duff, 1978; Hryniewicz et al., 2014).

These semi-infaunal/shallow infaunal bivalves lived close to the sediment-water interface and are indicative of at least periodic oxygenation. The semi-infaunal, byssally 


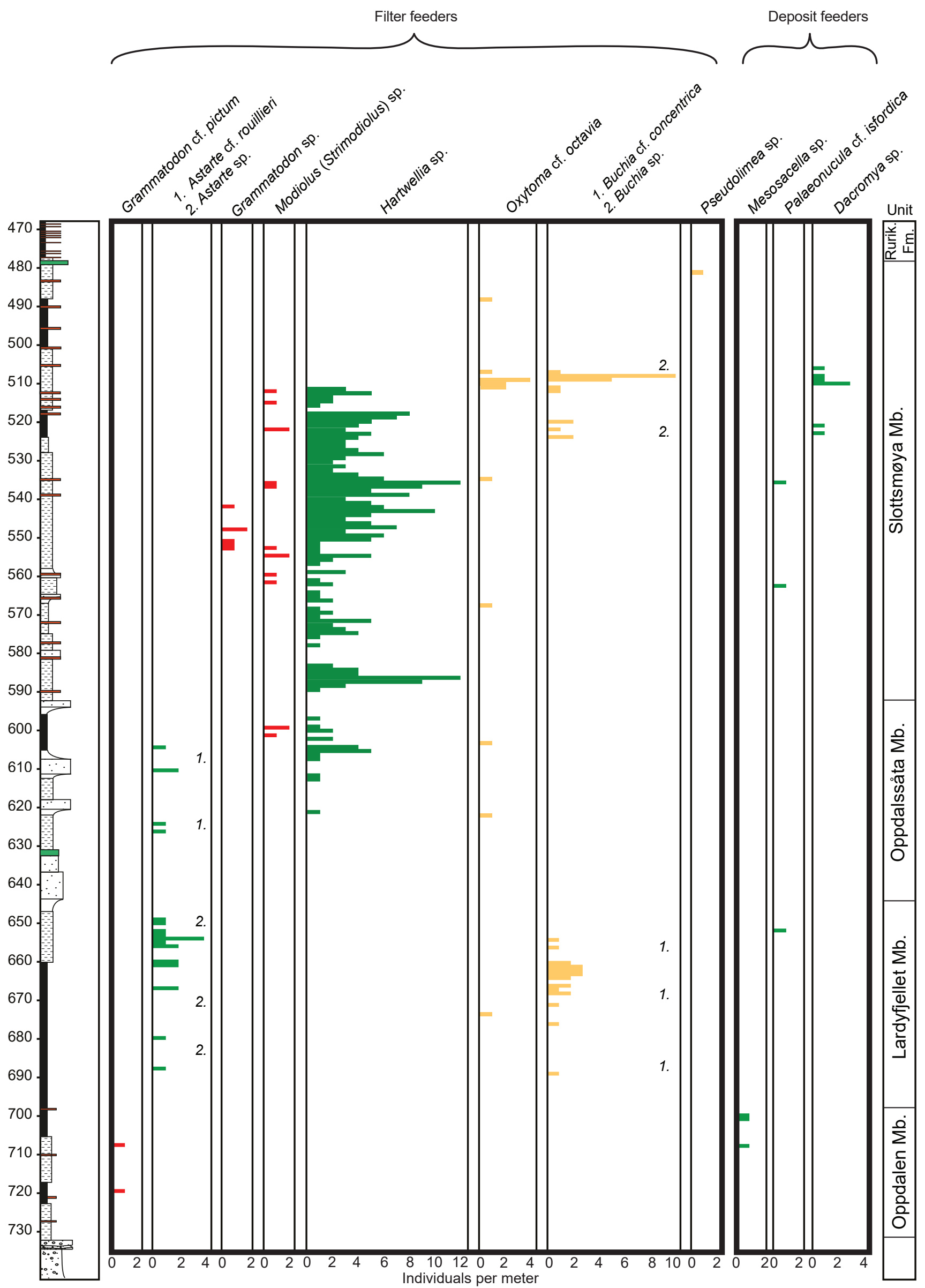

Figure 3. Identified bivalve occurrences in the DH2 core. Taxa grouped by feeding habits and life position. 

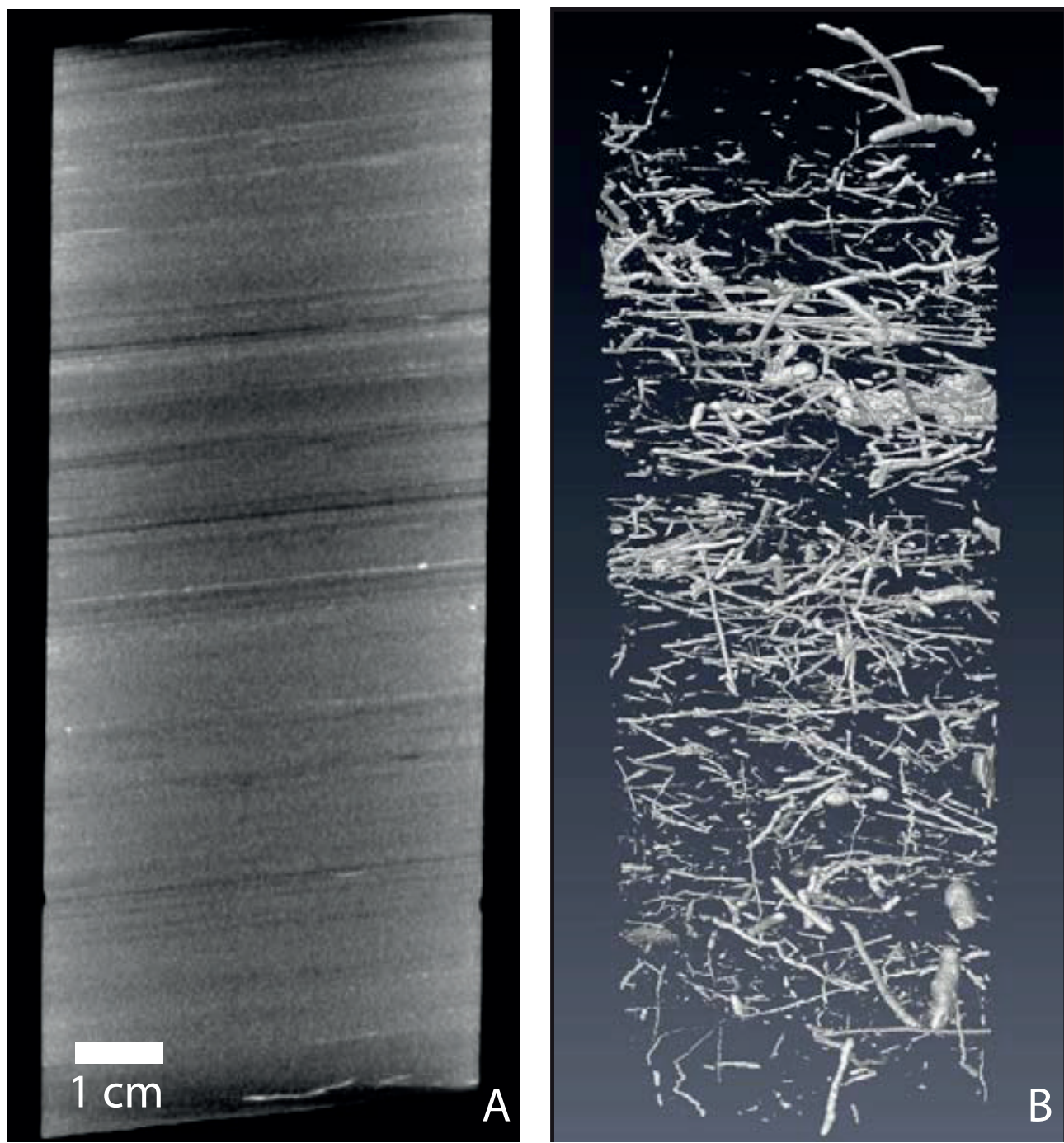

Figure 4. CT-scan images of sections of core from Well DH2. (A) At level $674 \mathrm{~m}$, Lardyfjellet Member. Unbioturbated laminated black shale. (B) At level 724 m, Oppdalen Member. Abundant Trichichnus in fine-grained siltstone.

attached G.cf.pictum (Stanley,1970) specimens were found in siltstones to fine-grained sandstones. These siltstones and sandstones were deposited near the storm wave base, under periodically dysoxic conditions (Koevoets et al., 2018). G. cf. pictum was well adapted to moderately energetic conditions, feeding on suspended organic matter (Stanley, 1970). Mesosaccella sp. was encountered in the uppermost Oppdalen Member, where dysoxic/ anoxic silty mudstones/black shales dominate (Koevoets et al., 2018). This occurrence is expected, as Mesosaccella is associated with dysoxic conditions in other formations (Wignall, 1990; Kenig et al., 2004). Being infaunal deposit feeders, Mesosaccella specimens spent most of their lives buried. Hodges (2000) suggests that Mesosaccella could have had a short siphon for respiration and/or feeding from the sediment-water interface, and which could have been used as a snorkel during periodic deoxygenation events. If conditions become too challenging it is possible that individuals would have risen to the substrate surface to extend their siphons into oxygenated waters above.
Figure 5. Hartwellia sp.: (A1) External mould of left valve, DH2 535.48 m, Slottsmøya Member, middle Volgian (PMO 228.777). (A2) Magnification of dentition of underlying valve (PMO 228.777). (B) External mould of left valve, DH2 $584.06 \mathrm{~m}$, Slottsmøya Member, lower? Volgian (PMO 228.825). (C) External mould of opened articulated valves, DH2 $583.21 \mathrm{~m}$, Slottsmøya Member, lower? Volgian (PMO 228.823). (D) External mould of valve fragment, DH5 496.20 $m$, Slottsmøya Member, middle Volgian (PMO 228.915). (E) External mould of left valve, DH2 601.45 m, Oppdalssåta Member, lower Volgian? (PMO 228.836). (F) External mould of opened articulated valves, DH2 $552.60 \mathrm{~m}$, Slottsmøya Member, middle Volgian (PMO 228.800). Cadoceras sp. indet.: (G) External mould of outer whorl, lateral view, DH2 724.10 m, Oppdalen Member, Upper Bathonian (PMO 228.887). Amoebites cf. subkitchini: (H) External mould of lateral view, keel visible, DH2 $679.34 \mathrm{~m}$, Lardyfjellet Member, Lower Kimmeridgian (PMO 228.872). Hoplocardioceras elegans: (I) External mould of outer whorl fragment, Criocerasaksla (glauconitic bed), Oppdalssåta Member, Upper Kimmeridgian (PMO 228.924). Amoebites sp. indet.: (J) External mould of lateral view, Janusfjellet (lowermost siltstone), Oppdalssåta Member, Upper Kimmeridgian (PMO 228.921). Amoebites spathi: (K) External mould of lateral view, DH2 666.19 m, Lardyfjellet Member, Lower Kimmeridgian (PMO 228.855 A). Amoebites $c f$. pingueforme: (L) External mould of lateral view, DH2 666.75 m, Lardyfjellet Member, Lower Kimmeridgian (PMO 228.857 B). 


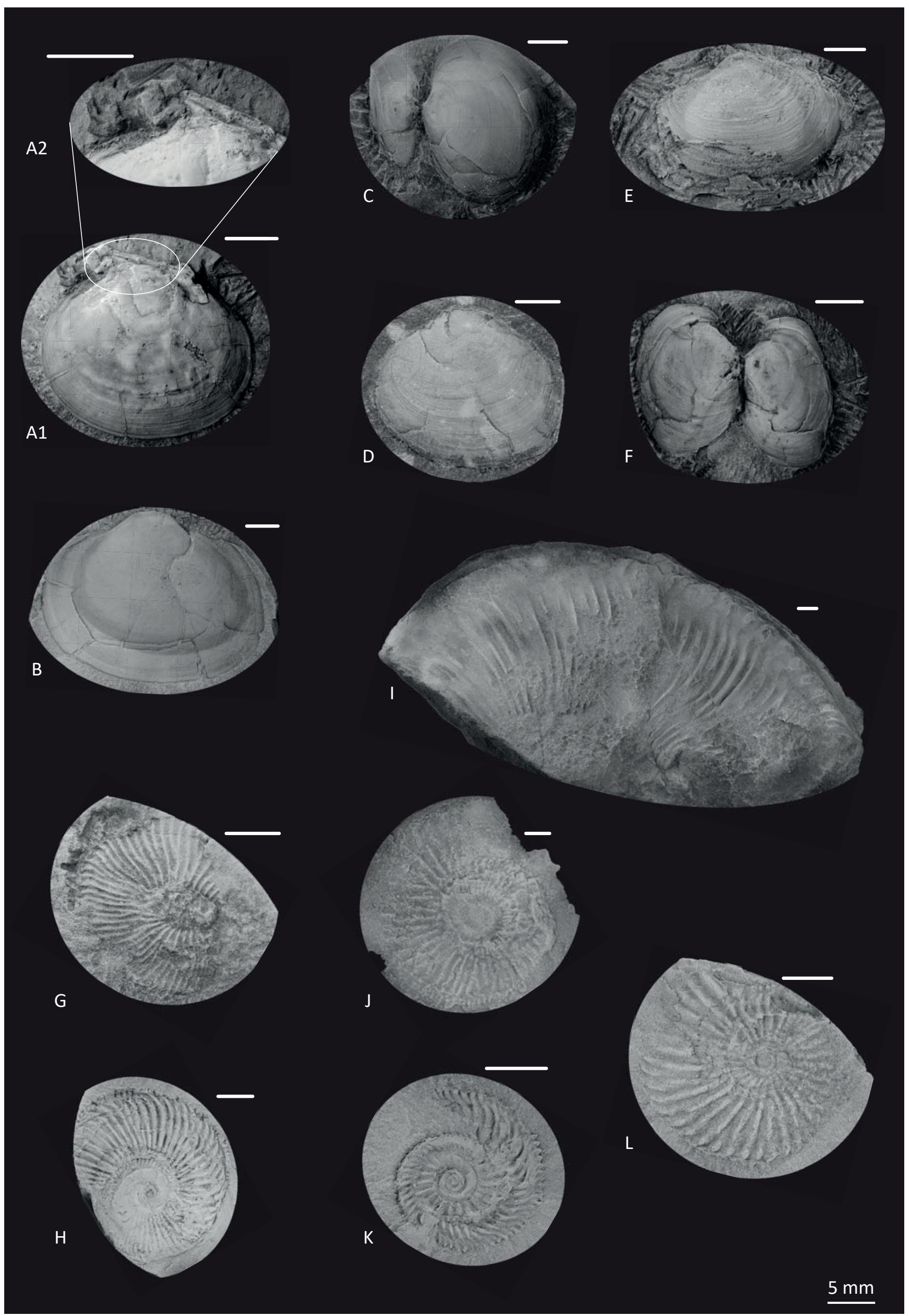




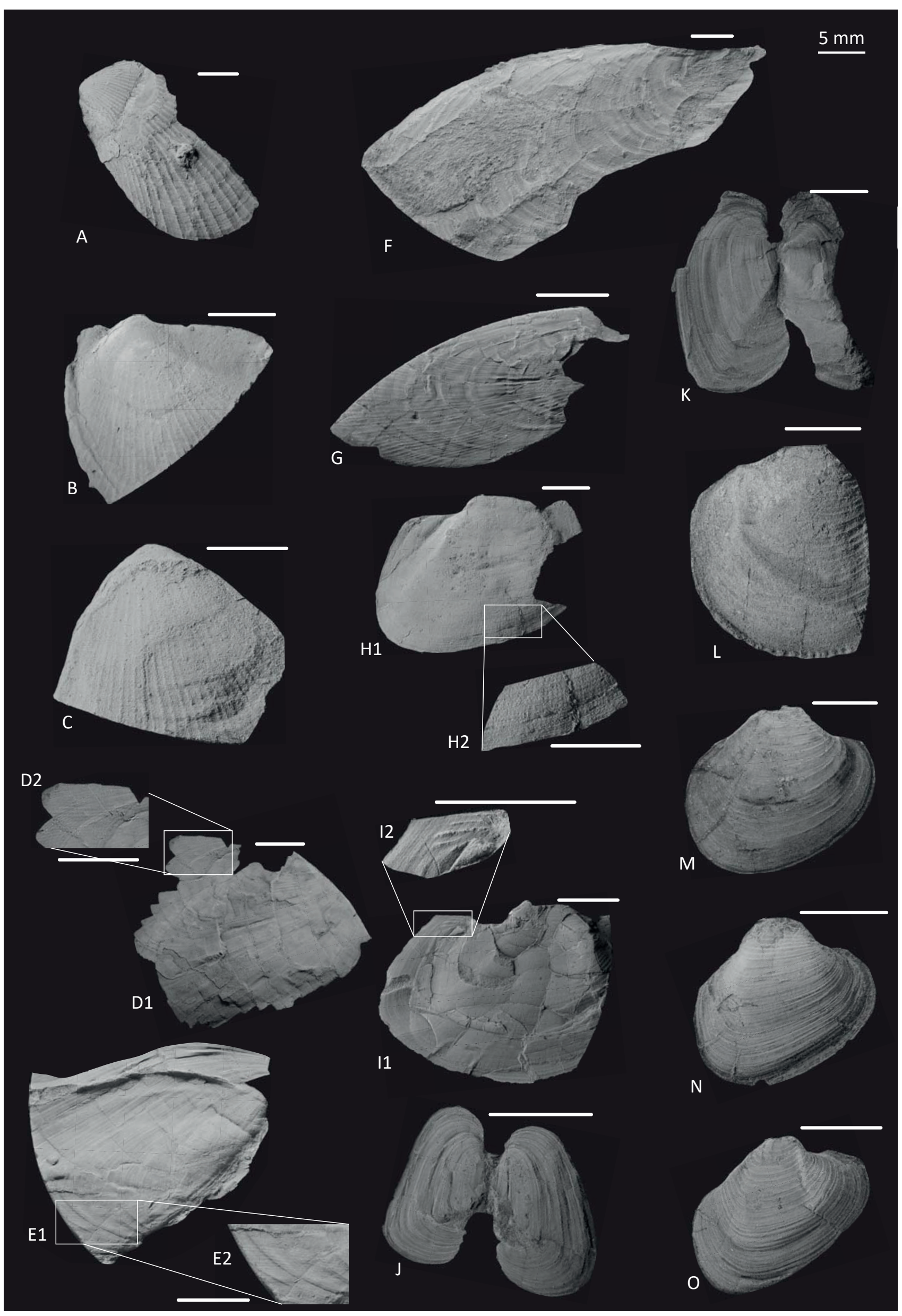


Figure 6. Pseudolimea sp:: (A) External mould of right valve fragment, DH2 $480.72 \mathrm{~m}$, Slottsmøya Member, Ryazanian (PMO 228.745). Oxytoma cf. octavia: (B) External mould of left valve fragment, DH2 $510.72 \mathrm{~m}$, Slottsmøya Member, upper Volgian (PMO 228.758). (C) External mould of left valve fragment, DH2 510.66 $m$, Slottsmøya Member, middle Volgian (PMO 228.757). Modiolus (Strimodiolus) sp.: (D1) External mould of valve fragment, DH2 $518.38 \mathrm{~m}$, Slottsmøya Member, middle Volgian (PMO 228.763). (D2) Magnification of valve ornamentation (PMO 228.763). (E1) External mould of left valve fragment, DH2 $601.29 \mathrm{~m}$, Oppdalssåta Member, lower Volgian? (PMO 228.835). (E2) Magnification of valve ornamentation (PMO 228.835). (F) External mould of right valve fragment, DH2 535.10 m, Slottsmøya Member, middle Volgian (PMO 228.780). (G) External mould of left valve fragment, DH2 $521.05 \mathrm{~m}$, Slottsmøya Member, middle Volgian (PMO 228.769). Grammatodon $c f$. pictum: (H1) External mould of right valve, $D H 2$ 720.67 m, Oppdalen Member, Upper Bathonian? (PMO 228.886). (H2) Magnification of valve ornamentation (PMO 228.886). (I1) External mould of left valve? \& underlying valve, DH2 $708.02 \mathrm{~m}$, Oppdalen Member, Oxfordian (PMO 228.880). (I2) Magnification of dentition of underlying valve visible through the upper valve due to compaction (PMO 228.880). Grammatodon sp.: (J) External mould of opened articulated valves, DH2 $554.44 \mathrm{~m}$, Slottsmøya Member, middle Volgian (PMO 228.792). (K) External mould of opened articulated valves, DH5R $485.43 \mathrm{~m}$, Slottsmøya Member, middle Volgian (PMO 228.913). Astarte $c f$. rouillieri: (L) External mould of valve fragment, DH2 $610.43 \mathrm{~m}$, Oppdalssåta Member, lower Volgian? (PMO 228.842). (M) External mould of right valve, DH2 604.38 $m$, Oppdalssåta Member, lower Volgian? (PMO 228.839). Astarte sp.: (N) External mould of right valve, DH2 $654.67 \mathrm{~m}$, Lardyfjellet Member, Lower to Upper Kimmeridgian (PMO 228.850). (O) External mould of right valve, DH2 $654.11 \mathrm{~m}$, Lardyfjellet Member, Lower to Upper Kimmeridgian (PMO 228.849).

At $724.3 \mathrm{~m}$ in DH2, microfocus CT imaging revealed a dense ichnofabric of pyritised, thread-like filaments with inclinations varying from horizontal to vertical (Fig. 4). Similar fabrics were seen at $711.4 \mathrm{~m}$ and $668.3 \mathrm{~m}$. These trace fossils are referred to the ichnogenus Trichichnus, which has recently been interpreted as remains of intrasediment, sulphide-oxidising bacterial mats (Kędzierski et al., 2015). In modern sediments, these bacterial mats form primarily in areas with high organic content and poor, but not zero, oxygenation.

An outer shelf, low to moderately energetic environment seems to agree with the bivalve taxa found in the Oppdalen Member. The order of occurrences of the bivalves can be explained by decreasing energy levels and dysoxia. It does not explain their rarity, as black shales are commonly known for well preserved and common invertebrate faunas (Wignall, 1990; Kenig et al., 2004). The specimen rarity could have been a result of persistent anoxic conditions, with only few and short oxygenated intervals. This is in agreement with the rarity of other benthic groups, such as gastropods.

\section{Lardyfjellet Member}

The coarsening-upward, regressional Lardyfjellet Member (Lower Kimmeridgian-Upper Kimmeridgian) consists of mostly laminated black shales and siltstones, which are moderately fossiliferous in the lower half, with increasing specimen abundance towards the upper part of the member. Koevoets et al. (2018) describe the environment as transitioning from outer shelf dysoxic/ anoxic to the distal part of a delta front, implying an increase in oxygenation and energy levels. Fossils become particularly abundant at 675-655 metres in the member, as the ammonites Amoebites spp. (Fig. 5H, J \& L) and Rasenia cymodoce (Koevoets et al., 2016) are encountered at several levels, with up to five specimens per metre core (Fig. 2). Bivalves are common, as are fish remains, and a few scaphopods occur. Curiously, the onychite abundance decreases in the same interval. This could be a result of preservational differences, as onychites are made of chitin, which was preserved better under oxygen-depleted conditions (Durska \& Dembicz, 2015). The bivalve occurrences in the Lardyfjellet Member can be divided into two assemblages: Buchia cf. concentrica (Fig. 7F-H) dominated the middle part of the member, transitioning into an Astarte sp. dominated assemblage in the uppermost, more silt-dominated part of the section.

Species in the genus Buchia were opportunistic epifaunal, epi-byssate suspension-feeders, commonly found in shallow to deep-marine facies (Fürsich, 1984; Wignall, 1990). A proposed life position for B. keyserlingi was given by Zakharov (1981, fig. 78). The abundance of Buchia cf. concentrica is highest at $671-661 \mathrm{~m}$. In this interval, the strata consist of black shales devoid of bioturbation, TOC around 10\% (Koevoets et al., 2016), and $\mathrm{V} /(\mathrm{V}+\mathrm{Ni})$ ratios indicative of dysoxic to anoxic conditions (Koevoets et al., 2018). These circumstances are in agreement with the epifaunal/epi-byssate lifestyle of Buchia and with the findings of Zell \& Stinnesbeck (2015) that buchiids lived an epifaunal lifestyle, and were able to survive both high and low oxygen conditions. An opportunistic species such as B. cf. concentrica could take advantage of changing conditions in the Lardyfjellet Member as the coastline prograded, supplying the bottom water with more nutrients and increasing oxygenation. In the Buchia dominated bivalve assemblage, other species occurring in order of abundance were Astarte sp. (Fig. $6 \mathrm{~N}, \mathrm{O}$ ) and Oxytoma sp. (Fig. 7N, O). The latter was an epibyssate filter feeder, living on hard substrates such as shells (Stanley, 1970; Hryniewicz et al., 2014).

Most species of Astarte were shallow infaunal filter feeders (Stanley, 1970) tolerating moderately energetic environments. The sediments in which these specimens were found were deposited in a distal prodelta environment where energy levels were relatively low, but higher than in the underlying interval, TOC was very high and oxygenation of the bottom water was relatively low (Koevoets et al., 2018). The siltstones of the Lardyfjellet 

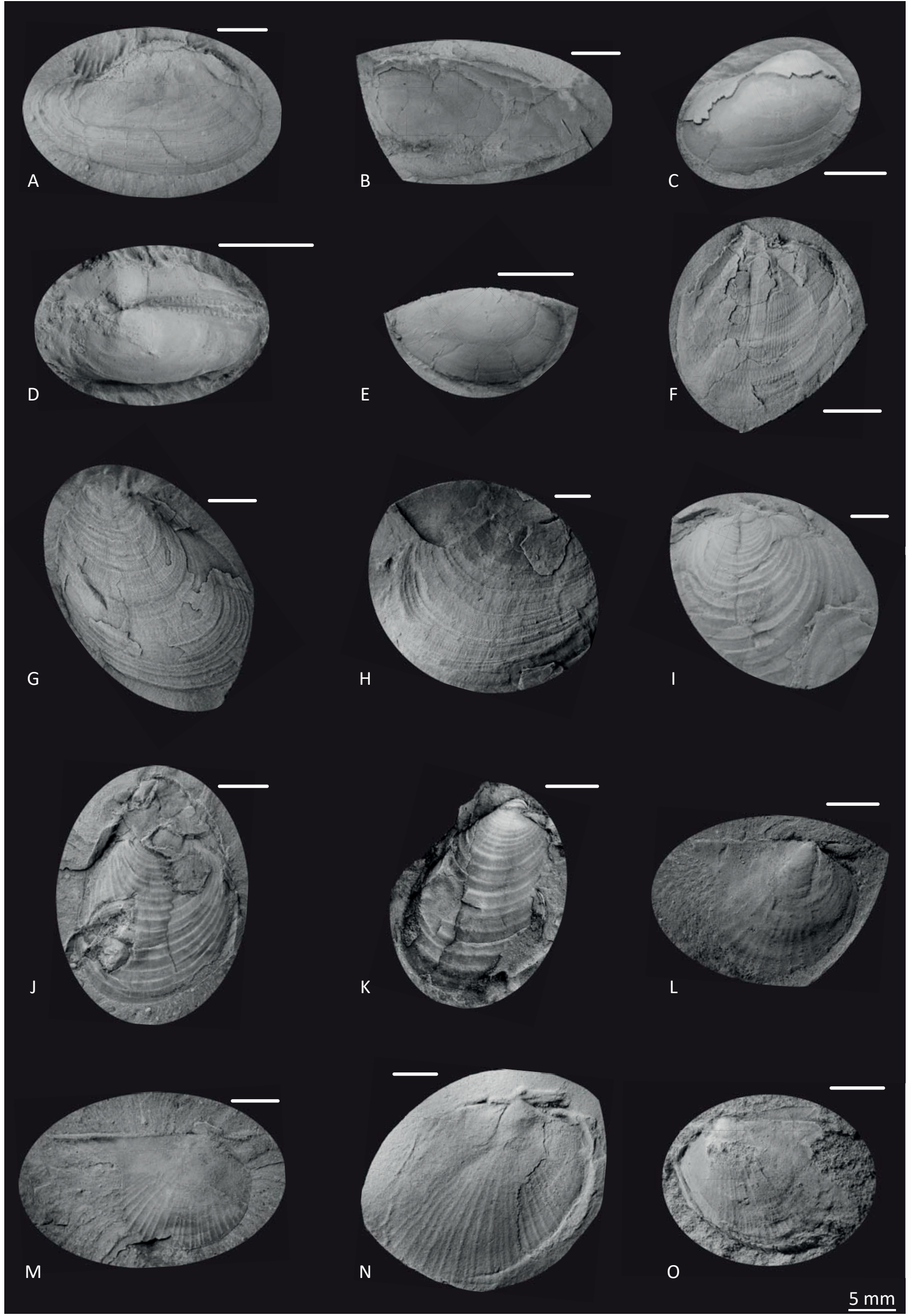
Figure 7. Dacromya sp.: (A) External mould of a left valve, DH2 $509.63 \mathrm{~m}$, Slottsmøya Member, middle Volgian (PMO 228.756). Palaeonucula $c f$. isfjordica: (B) External mould of dentition, dorsal view, DH2 505.95 m, Slottsmøya Member, middle Volgian (PMO 228.751). (C) Internal mould of right valve with shell partially preserved, Janusfjellet, Dorsoplanites bed, Slottsmøya Member, middle Volgian (PMO 228.911). (D) External mould of dentition, dorsal view, DH2 535.17 m, Slottsmøya Member, middle Volgian (PMO 228.776). Mesosaccella sp.: (E) External mould of valve, DH5R 658.10 m, Oppdalen Member, Bathonian-Callovian (PMO 228.912). Buchia cf. concentrica: (F) External mould of right valve fragment, DH2 $663.36 \mathrm{~m}$, Lardyfjellet Member, Lower Kimmeridgian (PMO 228.853). (G) External mould of left valve, DH2 663.87 m, Lardyfjellet Member, Lower Kimmeridgian (PMO 228.854). (H) External mould of right valve fragment, DH2 671.51 $m$, Lardyfjellet Member, Lower Kimmeridgian (PMO 228.863). Buchia sp.: (I) External mould of right valve fragment, DH2 505.96 $m$, Slottsmøya Member, middle Volgian (PMO 228.750). (J) External mould of left valve and underlying right valve, DH2 $519.81 \mathrm{~m}$, Slottsmøya Member, middle Volgian (PMO 228.766). (K) External mould of right valve fragment, DH2 $508.15 \mathrm{~m}$, Slottsmøya Member, middle Volgian (PMO 228.754). Oxytoma cf. octavia: (L) External mould of right valve, DH2 $506.48 \mathrm{~m}$, Slottsmøya Member, middle Volgian (PMO 228.752). (M) External mould of right valve, DH2 $509.21 \mathrm{~m}$, Slottsmøya Member, middle Volgian (PMO 228.755). Oxytoma sp.: (N) External mould of right valve, DH2 $674.95 \mathrm{~m}$, Lardyfjellet Member, Lower Kimmeridgian (PMO 228.865). (O) External mould of left valve, DH2 622.47 m, Oppdalssåta Member, Upper Kimmeridgian (PMO 228.843).

Member hosting the Astarte assemblage were not only bioturbated by the shallow infaunal bivalves, but also contain Teichichnus, Palaeophycus and small Chondrites trace fossils. The Lardyfjellet Member Astarte assemblage also contains $B$. cf. concentrica and, sporadically, the infaunal deposit feeder Palaeonucula cf. isfjordica (Fig. $7 \mathrm{~B}-\mathrm{D})$, the latter possibly indicating reduced oxygenation conditions.

The transition from a low hydro-energetic environment (laminated shales) to a moderate hydro-energetic environment (siltstones) is accompanied by a change from assemblages dominated by epifaunal bivalves to infaunal bivalves. The overall increase in diversity of invertebrate fauna can be an indication of more favourable living conditions, such as an increase in nutrient supply in the water column.

\section{Oppdalssåta Member}

The Oppdalssåta Member (Upper Kimmeridgian?Volgian) is characterised by thick tabular beds of finegrained sandstones, containing cross-stratification and commonly capped with shell beds (Dypvik et al., 1991b; Mørk et al., 1999; Koevoets et al., 2018). It is a series of coarsening-upward sequences in a slowly retrograding system (Koevoets et al., 2018). The transgression resulted in finer-grained sediments in every coarsening-upward (CU) unit. Bivalves are less common in the sandstones and only one genus (Astarte) is found in these sediments. However, after flooding of the basin and the deposition of siltstones/shales in the upper part of the member, infaunal bivalve genera such as Hartwellia and Modiolus (Strimodiolus) are relatively common, and epifaunal genera, such as Oxytoma, appear repeatedly. In the Oppdalssåta Member, the nektic invertebrate fauna decreases drastically: ammonites all but disappear, and onychites are absent until the appearance of the lowenergetic deposits in the final CU unit of the member. Teleost fish respond in a similar fashion. The only group profiting from the higher energetic conditions seems to be the gastropods. The gastropods preserved in this part of the section resemble procerithids, belonging to the superfamily Cerithioidea, which are often associated with higher energetic, oxygenated, bottom-water conditions (Allmon, 1988; Anderson et al., 2017). In this interval they have also been observed in the field in large numbers locally in fine-grained sandstone beds.

Hartwellia first occurs in the Upper Kimmeridgian and increases in abundance throughout the Oppdalsåta Member. Hartwellia sp. (Fig. 5A-F) was most likely a shallow infaunal suspension feeder, living close to the sediment-water interface, based on shell morphology (Stanley, 1970; Fürsich, 1982). Most specimens are entire and articulated, and some are in life position, indicating there was little to no transportation after death. Hartwellia sp. was found in the distal part of a retrograding prodelta system (Koevoets et al., 2018). The presence of the semiinfaunal Modiolus (Strimodiolus) sp. (Fig. 6D-G) and epifaunal Oxytoma sp. (Stanley, 1970; Fürsich, 1982) are also indicative of lower energetic environments. Astarte cf. rouillieri replaces Astarte sp. in this member and occurs in fine-grained sandstone beds, i.e., a coarser sediment than its Lardyfjellet Member counterpart, which occurs in siltstones. As infaunal filter feeders, many of the species within the genus Astarte were adaptable to moderately energetic environments (Stanley, 1970).

An alternation of a slightly higher energetic environment with low-energetic shales and siltstones (Fig. 3) coincides with the changes in abundances of the infaunal Hartwellia sp., and the presence or absence of Modiolus (Strimodiolus) sp. and Oxytoma sp. (semi-infaunal and epifaunal, respectively). The siltstones and shales bear the majority of the specimens and only few specimens, generally unidentifiable, occur in the sandstones. The interpretation of the coarsening-upward sequences as transitioning from outer shelf to transition zone/prodelta to lower middle shoreface/delta front can explain the alternating invertebrate abundances. Alternatively, the paucity of specimens in the sands could have taphonomic explanations, including a high sedimentation rate causing dilution of specimens. 


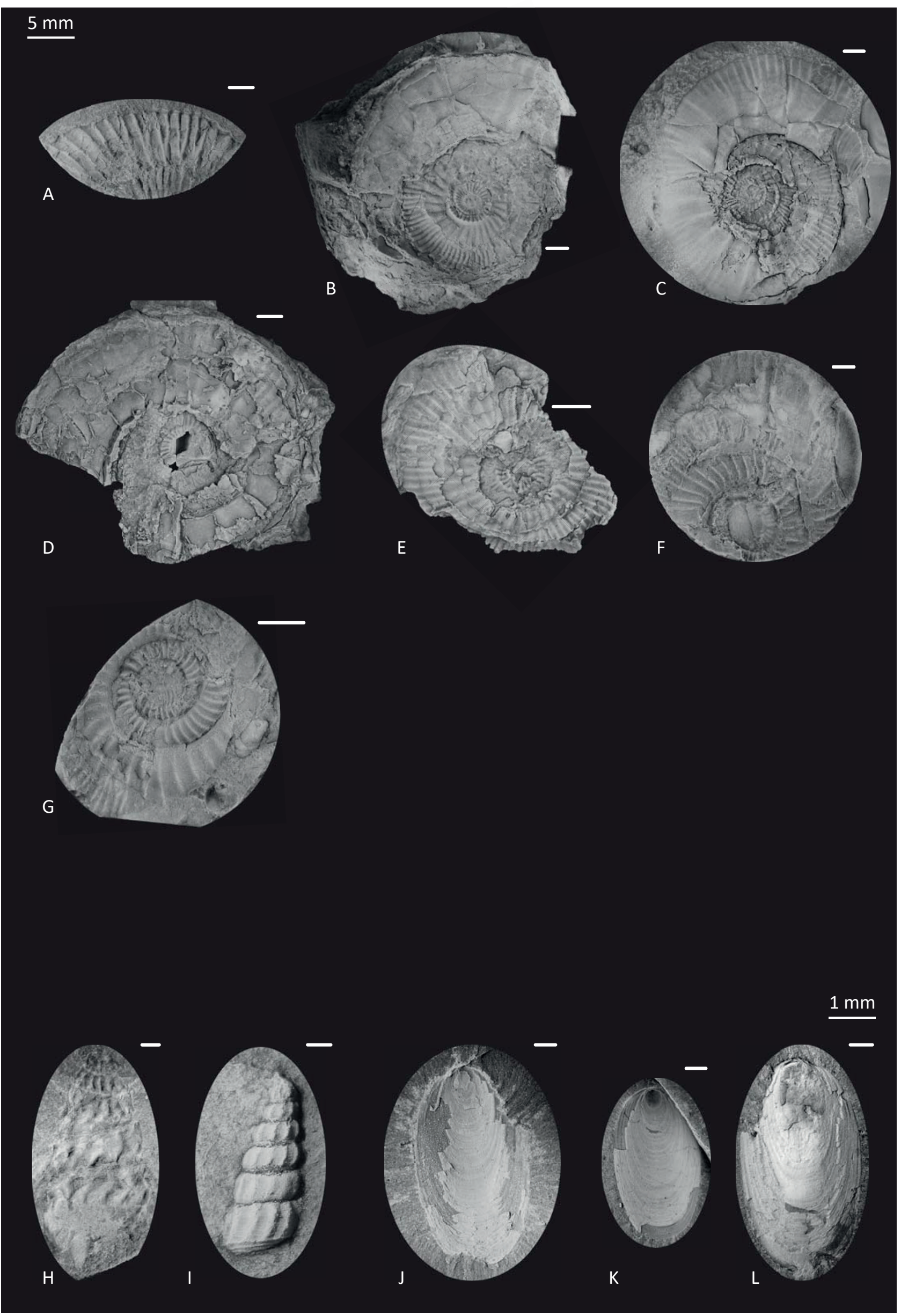


Figure 8. Pavlovia cf. iatriensis: (A) External mould of whorl fragment, DH2 $543.09 \mathrm{~m}$, Slottsmøya Member, middle Volgian (PMO 228.788). Epivirgatites cf. sokolovi (Bodylevskii in Rogov, 2010): (B) External mould of lateral view, Janusfjellet (Dorsoplanites bed), Slottsmøya Member, middle Volgian (PMO 228.932). (C) Internal mould of lateral view, Janusfjellet (Dorsoplanites bed), Slottsmøya Member, middle Volgian (PMO 228.930). (D) Internal mould of lateral view, Janusfjellet (Dorsoplanites bed), Slottsmøya Member, middle Volgian (PMO 228.929). Dorsoplanites/Epivirgatites indet.: (E) External mould of lateral view, Janusfjellet (Dorsoplanites bed), Slottsmøya Member, middle Volgian (PMO 228.928). Praechetaites ex gr. exoticus: (F) External mould of lateral view, DH2 $511.34 \mathrm{~m}$, Slottsmøya Member, middle Volgian (PMO 228.760). Laugeites sp.: (G) External mould of lateral view, DH2 507.95 m, Slottsmøya Member, middle Volgian (PMO 228.753). Procerithid gastropods: (H) External mould of compressed shell, DH2 $581.81 \mathrm{~m}$, Slottsmøya Member, lower Volgian? (PMO 228.824). (I) Silicone rubber cast of external mould, DH2 711.40, Oppdalen Member, Callovian (PMO 228.882). Lingularia sp.: (J) Pedicle valve internal mould with shell fragments, DH2 $482.20 \mathrm{~m}$, Slottsmøya Member, Ryazanian (PMO 228.747 (1)). (K) Pedicle valve internal mould with shell fragments, DH2 482.20 m, Slottsmøya Member, Ryazanian (PMO 228.747 (2)). (L) Pedicle valve internal mould with shell fragments, DH2 482.20 $m$, Slottsmøya Member, Ryazanian (PMO 228.746).

\section{Slottsmøya Member}

The overall abundance of invertebrate fauna in the Agardhfjellet Formation is highest in the Slottsmøya Member. The semi-infaunal scaphopods become more common, and onychites, ammonites and fish remains occur regularly throughout the member. All of the identifiable ammonites were found in the middle to upper Volgian interval, including Dorsoplanites cf. maximus, Epivirgatites cf.sokolovi (Fig. 8B-D), Dorsoplanites sp.(Fig. 9J, K), Praechetaites ex gr. exoticus (Fig. 8F) and Laugeites sp. (Fig. 8G). The bivalve assemblage is dominated by Hartwellia sp., which increases dramatically in abundance in the section. Also occurring in the Slottsmøya Member are the semi-infaunal taxa Grammatodon sp. (Fig. 6J, $\mathrm{K})$ and Modiolus (Strimodiolus) sp., and in places the deposit-feeding Palaeonucula cf. isfjordica (Stanley, 1970; Fürsich, 1982). Another bivalve assemblage occurs from about $530 \mathrm{~m}$ to $520 \mathrm{~m}$ in the member comprising mainly of epifaunal taxa, such as Buchia sp. (Fig. 7I-K), Oxytoma cf. octavia (Figs. 6B, C \& 7L, M), and Pseudolimea sp. (Fig. 6A), and the deposit-feeding Dacromya sp. (Fig. 7A).

The Hartwellia assemblage is found in an alternating oxic-dysoxic, regressive, outer-shelf marine environment (Koevoets et al., 2018). Modiolus (Strimodiolus) sp. is believed to have been an endobyssate, low-level (bottom 5 $\mathrm{cm}$ of the water column) suspension feeder (Stanley, 1970;
Fürsich, 1982). Specimens belonging to these taxa were found in muddy siltstones typical for outer-shelf marine deposits (Koevoets et al., 2018). According to Collignon \& Hammer (2012) the bottom waters of the Slottsmøya Member were periodically oxygenated, as a result of a sudden incoming of reworked sediments (siltstones to very fine sandstones) deposited as parts of turbidites or storm deposits. This conclusion is confirmed by element analysis of Koevoets et al. (2018) where V / (V + Ni) and $\mathrm{U} / \mathrm{Th}$ ratios are used as oxygenation proxies.

There is a remarkable increase in onychites specimens and teleost remains in the uppermost part of the Slottsmøya Member, in the interval 493-500 $\mathrm{m}$ in DH2 (Fig. 2). This increase is followed by a sudden peak of abundance of lingulid brachiopods, and the onychite and teleost remains disappear. During this interval the numbers of bivalves and ammonites drop drastically, and the lithology changes from siltstone to laminated black shale. Just below this interval, infaunal bivalves become very rare and are replaced by epifaunal species such as Buchia sp., Oxytoma cf. octavia, Pseudolimea sp., and the infaunal deposit feeder Dacromya sp. All these changes point to a sudden deepening of the basin and increased input of organic matter, creating more anoxic bottom waters.

Buchia sp. was most likely an opportunistic epi-byssate filter feeder, like B. cf. concentrica, which fits with a sudden decrease in energy levels and the early onset of increased oxic conditions. O. octavia and Pseudolimea sp. were filter feeders (Stanley, 1970) that lived byssally attached to loose shells or hard substrates, such as authigenic carbonate crusts from the hydrocarbon seeps (Hammer et al., 2011) which occur at this level (Hryniewicz et al., 2014). O. octavia most likely lived in low-energy environments, based on their thin shells (Hryniewicz et al., 2014). The specimens in this study were collected from an interval that belongs to a transgressional sequence (Koevoets et al., 2018), just below a maximum flooding surface. The depositional environment of this interval is assigned to the outer-shelf marine realm (Koevoets et al., 2018), which fits the findings of Hryniewicz et al. (2014) on the low-energy environment habitat for O. octavia.

Dacromya sp. was an infaunal deposit-feeding bivalve. The high mud percentage of the siltstones containing Dacromya indicates a low-energy deposit. The presence of this burrowing bivalve indicates a periodic oxygenation of the seafloor and the top layers of the substrate. The TOC content of this interval is 2-5\% (Koevoets et al., 2016), potentially a good food source for a deposit-feeding species (Stanley, 1970).

The siltstones overlying the black shales do not show a recovery of the invertebrate benthic fauna. Onychites and teleosts disappear and only a few bivalves are present (Pseudolimea sp. and O. cf. octavia). A bed follows with large numbers of the brachiopod Lingularia sp. (Fig. 2). 


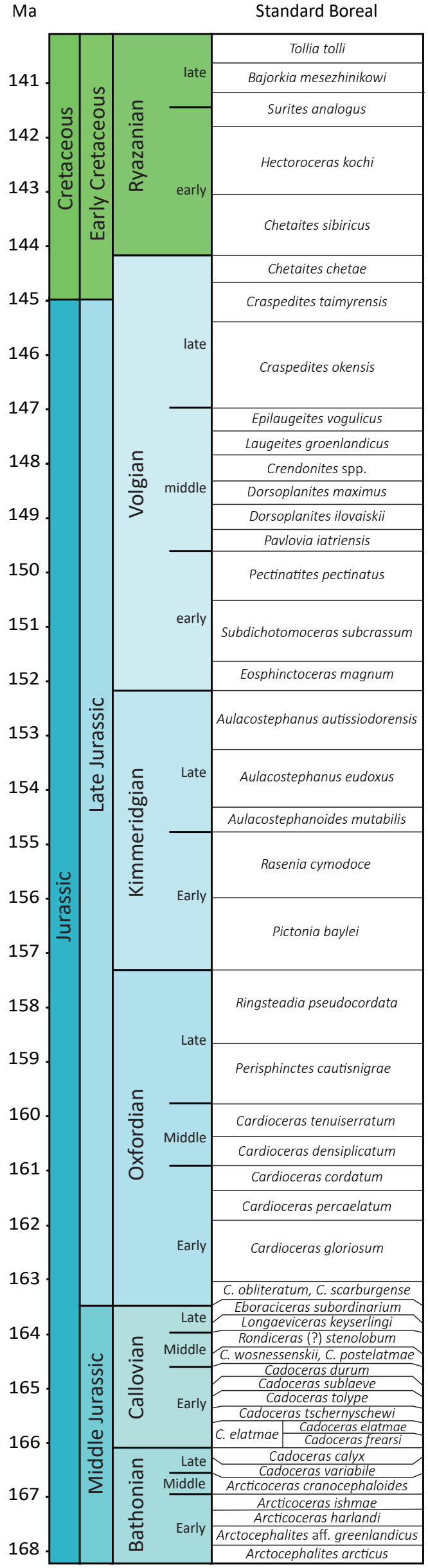

Central Spitsbergen

Northern Asian Russia

East Greenland

\begin{tabular}{|c|c|c|c|c|}
\hline & Tollia tolli & & Tollia tolli & Peregrinoceras aff. albidum \\
\hline \multicolumn{2}{|c|}{ Surites tzikwinianus } & \multicolumn{2}{|c|}{ Bajorkia mesezhinikowi } & Surites tzikwinianus \\
\hline \multicolumn{2}{|c|}{ Surites analogus } & \multicolumn{2}{|c|}{ Surites analogus } & Surites analogus \\
\hline \multicolumn{2}{|c|}{ Hectoroceras kochi } & \multicolumn{2}{|c|}{ Hectoroceras kochi } & Hectoroceras kochi \\
\hline \multicolumn{2}{|c|}{ Chetaites sibiricus } & \multicolumn{2}{|c|}{ Chetaites sibiricus } & Praetollia maynci \\
\hline \multirow{2}{*}{\multicolumn{2}{|c|}{ Craspedites taimyrensis }} & \multicolumn{2}{|c|}{ Chetaites chetae } & \multirow{5}{*}{ Subcraspedites sowerbyi? } \\
\hline & & \multicolumn{2}{|c|}{ Craspedites taimyrensis } & \\
\hline \multirow{3}{*}{\multicolumn{2}{|c|}{ Craspedites okensis }} & \multirow{3}{*}{ 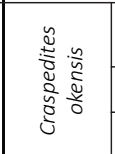 } & $\begin{array}{c}\text { Subcraspedites } \\
\text { originalis }\end{array}$ & \\
\hline & & & Craspedites okensis & \\
\hline & & & Praechetaites exoticus & \\
\hline \multirow{2}{*}{\multicolumn{2}{|c|}{$\begin{array}{c}\text { Praechetaites exoticus } \\
-1---1---1--- \\
\text { Laugeites groenlandicus }\end{array}$}} & \multicolumn{2}{|c|}{ Epilaugeites vogulicus } & Praechetaites tenuicostatus \\
\hline & & \multicolumn{2}{|c|}{ Laugeites groenlandicus } & $\begin{array}{l}\text { Epilaugeites vogulicus } \\
\text { Laugeites groenlandicus }\end{array}$ \\
\hline \multicolumn{2}{|c|}{ Crendonites anguinus } & \multicolumn{2}{|c|}{ Crendonites spp. } & Crendonites anguinus \\
\hline \multicolumn{2}{|c|}{ Dorsoplanites maximus } & \multicolumn{2}{|c|}{ Dorsoplanites maximus } & Epipallasiceras pseudapertum \\
\hline \multicolumn{2}{|c|}{ Dorsoplanites ilovaiskii } & \multicolumn{2}{|c|}{ Dorsoplanites ilovaiskii } & D. gracilis / D. liostracus \\
\hline \multicolumn{2}{|c|}{ Pavlovia rugosa } & & Jovia iatriensis & Pavlovia spp. \\
\hline & & Pectir & natites pectinatus & Pectinatites pectinatus \\
\hline & & & & Pectinatites hudlestoni \\
\hline & tinatites spp. & Sphinct & oceras subcrassum & Pectinatites wheatleyensis \\
\hline & & Eosphir & nctoceras magnum & Pectinatites elegans \\
\hline Subox & yiscites taimyrensis & Suboxy & discites taimyrensis & Aulocostephanus cf. kirghisensis \\
\hline Hoplo & rdioceras decipiens & & & Hoplocardioceras elegans \\
\hline Eup & noceras sokolovi & Amoe & eboceras elegans & $\begin{array}{c}\text { Hoplocardioceras decipiens } \\
\text { Amoebites kochi }\end{array}$ \\
\hline & Amoebites modestum & Amc & oeboceras kochi & Aulacostephanoides mutabilis \\
\hline 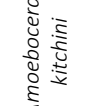 & Amoebites subkitchini & $\tilde{\check{\Xi}}: \overline{0}$ & Rasenia borealis & $\begin{array}{l}\text { Amoebites aff. rasenense } \\
\text { Amoebites aff. subkitchini } \\
\text { "Pachypictonia" } \\
\text { Amoebites subkitchini }\end{array}$ \\
\hline & Amoebites bayi & 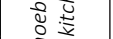 & & Amoebites bayi \\
\hline & natites bauhini & & Pictonia involuta & \\
\hline Amoe & ceras rosenkrantzi & पूus & $\begin{array}{c}\text { Amoeboceras } \\
\text { rosenkrantzi }\end{array}$ & Amoeboceras rosenkrantzi \\
\hline Amc & boceras regulare & है & $\begin{array}{c}\text { Amoeboceras } \\
\text { regulare }\end{array}$ & Amoeboceras regulare \\
\hline Amo & boceras serratum & Amoe & boceras serratum & Amoeboceras serratum \\
\hline Amo & boceras ilovaiskii & Amoe & boceras glosense & Amoeboceras glosense \\
\hline C. ( & ) tenuiserratum & Cardioc & eras tenuiserratum & Cardioceras tenuiserratum \\
\hline & ) densiplicatum & Cardioce & eras densiplicatum & Cardioceras densiplicatum \\
\hline Carc & ceras cordatum & Cardi & $\begin{array}{l}\text { oceras cordatum } \\
\text { ceras percaelatum }\end{array}$ & Cardioceras cordatum \\
\hline & & Cardioce & $\begin{array}{l}\text { ras (Scarburgiceras) } \\
\text { gloriosum }\end{array}$ & \\
\hline & obliteratum? & $\begin{array}{l}\text { Cardioce } \\
\text { oblitera }\end{array}$ & $\begin{array}{l}\text { ras (Scarburgiceras) } \\
\text { tum-scarburgense }\end{array}$ & Quenstedtoceras mariae \\
\hline & & Eboracic & $\begin{array}{l}\text { ceras subordinarium } \\
\text { eviceras keyserlingi }\end{array}$ & $\begin{array}{c}\text { Quenstedtoceras lamberti } \\
\text { Peltoceras athleta }\end{array}$ \\
\hline Long & viceras keyserlingi & Rondice & eras (?) stenolobum & Erymnoceras coronatum \\
\hline & & C. wosness & senskii, C. postelatmae & Kosmoceras jason \\
\hline & & $\begin{array}{r}\mathrm{Cad} \\
\mathrm{Cad} \\
\mathrm{Ca}\end{array}$ & $\begin{array}{l}\text { doceras durum } \\
\text { oceras sublaeve }\end{array}$ & Sigaloceras calloviense \\
\hline & & Cadoce & ras tschernyschewi & Cadoceras nordenskjoeldi \\
\hline & ceras apertum & C. elatmae & \begin{tabular}{|c|} 
Cadoceras elatmae \\
Cadoceras frearsi \\
\end{tabular} & Cadoceras apertum \\
\hline & oceras calyx & & doceras calyx & Cadoceras calyx \\
\hline Arcticoc & as cranocephaloides & $\begin{array}{r}\text { Cadt } \\
\text { Arcticocel } \\
\text { Arct } \\
\text { Arcti }\end{array}$ & $\begin{array}{l}\text { oceras variabile } \\
\text { ras cranocephaloides } \\
\text { icoceras ishmae } \\
\text { coceras harlandi }\end{array}$ & $\begin{array}{c}\text { Cadoceras variabile } \\
\text { Arcticoceras cranocephaloides } \\
\text { Arcticoceras ishmae }\end{array}$ \\
\hline & & Arctocepha & lites aff. greenlandicus & Arctocephalites greenlandicus \\
\hline & coceras & Arctoc & cephalites arcticus & Arctocephalites arcticus \\
\hline
\end{tabular}




\section{Comparison with other Arctic Upper Jurassic localities}

\section{Ammonites}

In order to correlate other sections to the Agardhfjellet Formation of Spitsbergen, a high-resolution biostratigraphy is necessary. Ammonites of the Mesozoic show provincialism and can be divided into two realms: the Tethyan Realm and the Boreal Realm (Krymholts \& Mesezhnikov, 1988; Gradstein et al., 2012). This makes correlation with stratigraphy in the UK and Europe challenging, but not impossible, as demonstrated by Gradstein et al. (2012) and Rogov \& Zakharov (2009). In the Boreal Arctic, several studies have been done on the ammonite biostratigraphy of sections in Spitsbergen, northern Siberia and East Greenland (Callomon, 1959; Kopik \& Wierzbowski, 1988; Århus et al., 1989; Surlyk, 1991; Rogov \& Zakharov, 2009; Rogov et al., 2011; Wierzbowski et al., 2011; Pauly et al., 2012; Alifirov et al., 2015; Rogov, 2016) (Table 1).

In Spitsbergen, the ammonite occurrences, preservation, and occurrence of condensed sections and possible hiatuses have limited the determination of ammonite zones in the Bathonian, Callovian and Oxfordian. The ammonites found in the Agardhfjellet Formation in the $\mathrm{DH} 2$ core correspond well with the previously indicated biostratigraphy. An unidentified cardioceratid occurs at $718 \mathrm{~m}$ in DH2, and at $724 \mathrm{~m}$ Cadoceras sp. was found. Kepplerites (S.) svalbardensis (DH5R, $663 \mathrm{~m}$ ) in the Oppdalen Member belongs to the NW European Clydoniceras discus Zone (Koevoets et al., 2016), which corresponds with the Boreal standard Cadoceras calyx Zone (Table 1). Cardioceras sp. (DH2, $706 \mathrm{~m}$ ) from the uppermost Oppdalen Member is believed to be part of the Cardioceras cordatum Zone (Koevoets et al., 2018), but without species identification it is difficult to pinpoint the age more precisely other than Oxfordian. The same applies to the cardioceratid at $701 \mathrm{~m}$ in DH2 in this study

Table 1. Ammonite zone correlation throughout the Arctic based on previous studies by Callomon (1959), Ershova (1983), Kopik \& Wierzbowski (1988), Rogov \& Zakharov (2009, 2011), Wierzbowski et al. (2011) and Rogov (2016) for Spitsbergen; Rogov \& Zakharov (2009, 2011), Rogov (2016) and Alifirov et al. (2015) for northern Asian Russia and Callomon (1959), Callomon \& Birkelund (1982), Birkelund \& Callomon (1985), Århus et al. (1989), Surlyk (1991), Rogov \& Zakharov (2009), Pauly et al. (2012) and Rogov (2014, 2016) for East Greenland. The standard Boreal zonation is based on Gradstein et al. (2012) and Nikitenko et al. (2013) with some adjustment in the Bathonian according to Mitta et al. (2014). Most of the Oxfordian zonation in Spitsbergen, based on Ershova (1983) and Rogov (2018), has so far not been recognised in outcrops in central Spitsbergen.
(Fig. 9C) which like Cardioceras sp. from the uppermost Oppdalen Member is assigned to the C. cordatum Zone.

In the upper half of the Lardyfjellet Member ammonites become very abundant. This interval $(680-660 \mathrm{~m}$ in $\mathrm{DH} 2$ ) is ascribed to the Lower Kimmeridgian Rasenia cymodoce Zone of the Boreal Standard, where in Spitsbergen and Siberia Amoebites subkitchini is used as an index species (Table 1) (Wierzbowski, 1989; Rogov, 2014, 2016; Koevoets et al., 2016). A. subkitchini (Fig. $5 \mathrm{H}$ ), A. pingueforme (Fig. 5L) and Rasenia cf. cymodoce (Fig. 9F, I) from this study all fall within the same interval. Koevoets et al. (2016) found Hoplocardioceras elegans in DH5R at $566 \mathrm{~m}$, corresponding to $626 \mathrm{~m}$ in $\mathrm{DH} 2$, and concluded that it belonged to either the Upper Kimmeridgian Aulacostephanus eudoxus Zone or the Euprinoceras sokolovi Zone of the Boreal Realm (Table 1). Other specimens of $H$. elegans were encountered a couple of metres below in DH5R (Fig. 9A) and at Janusfjellet just above the glauconitic sandstone of the Oppdalssåta Member (Figs. 5I \& 9B).

The ammonite zonation in the Slottsmøya Member based on the specimens from the DH2 and DH5R core is difficult, because no identifiable ammonites were found in the lower part of the member. The first identified ammonite in the DH2 core, Pavlovia cf. iatriensis at $543 \mathrm{~m}$ (Fig. 8A), indicates a middle Volgian age, as supported by finds of Dorsoplanites sp. at $543 \mathrm{~m}$ in DH2 and $488 \mathrm{~m}$ in DH5R (Fig. 9J, K). In the field, a sideritic bed, informally referred to as the Dorsoplanites bed, correlating to c. 536 $\mathrm{m}$ in $\mathrm{DH} 2$, is rich in fossils. From this bed, Dorsoplanites sp. (Fig. 9D) and Epivirgatites cf. sokolovi (Fig. 8B-D), of the middle Volgian, were recovered.

In the upper Volgian to Ryazanian interval of the Agardhfjellet Formation in DH2 ammonites are uncommon. Praechetaites ex gr. exoticus (Fig. 8F) at 511 $\mathrm{m}$ and Laugeites sp. (Fig. 8G) at $507 \mathrm{~m}$ in DH2 are found in the uppermost middle Volgian (Rogov, 2010).

Recently,Mikhail Rogov (pers.comm.and Rogov,2018) has sampled the DH2 core in high resolution for ammonites. His age determinations are in general agreement with those of Koevoets et al. (2018) for the lower part of the core (Oppdalen, Lardyfjellet and Oppdalssåta members, of Bathonian to Upper Kimmeridgian age). However, in the Slottsmøya Member, he assigns the uppermost part (c. 525-480 $\mathrm{m}$ in DH2) to the middle and upper Volgian, rather than the upper Volgian to Ryazanian of Koevoets et al. (2018). This is seemingly in conflict with the work of Wierzbowski et al. (2011) who reported upper Volgian to upper Ryazanian ammonites from hydrocarbon seeps in the Janusfjellet-Knorringfjellet area, all situated below the Myklegardfjellet Bed, which we have placed at 479 $\mathrm{m}$ in DH2 (Koevoets et al. 2018). Possible explanations for this discrepancy include strong diachronism, slumping of seep carbonates as well as problems with the ammonite zonation. We have tentatively followed Rogov's 


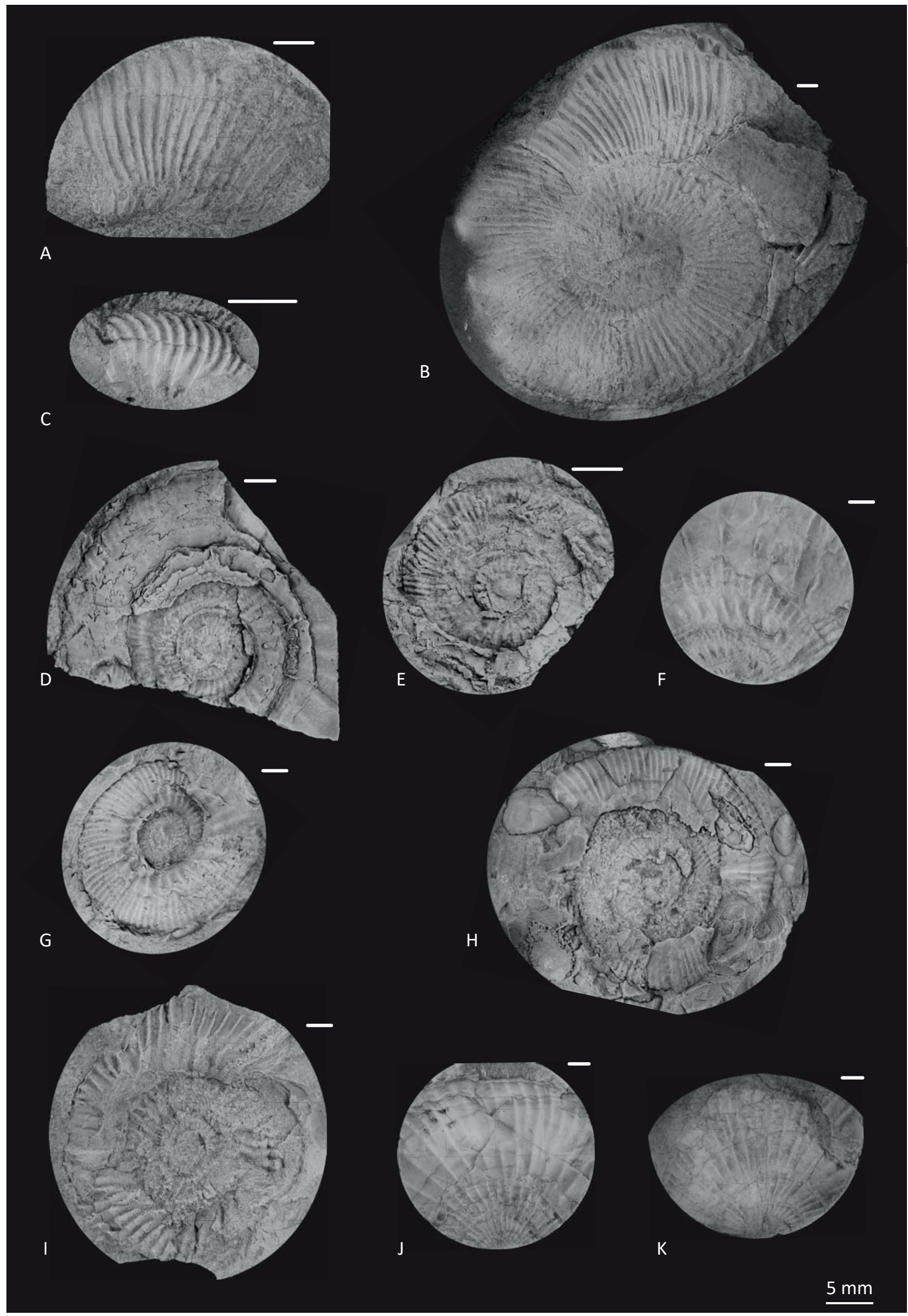


Figure 9. Hoplocardioceras elegans: (A) External mould of whorl fragment, DH5R $568.15 \mathrm{~m}$, Oppdalssåta Member, Upper Kimmeridgian (PMO 228.922). (B) External mould of lateral view, Criocerasaksla (glauconitic bed), Oppdalssåta Member, Upper Kimmeridgian (PMO 228.923). Cardioceratid: (C) External mould of whorl fragment, DH2 $700.88 \mathrm{~m}$, Oppdalen Member, Oxfordian (PMO 228.878). Dorsoplanites sp.: (D) Internal mould of lateral view fragment, Janusfjellet (Dorsoplanites bed), Slottsmøya Member, middle Volgian (PMO 228.927 (1)). Dorsoplanitid: (E) Internal mould of lateral view fragment, Janusfjellet (Dorsoplanites bed), Slottsmøya Member, middle Volgian (PMO 228.927 (2)). Zenostephanus sp.: (F) External mould of lateral view fragment, DH2 645.88 m, Oppdalssåta Member, Upper Kimmeridgian (PMO 228.847). Dorsoplanitids: $(G)$ External mould of lateral view, Janusfjellet (Dorsoplanites bed), Slottsmøya Member, middle Volgian (PMO 228.926 (1)). (H) External mould of lateral view, Janusfjellet (Dorsoplanites bed), Slottsmøya Member, middle Volgian (PMO 228.926 (2)). Rasenia?: (I) External mould of lateral view, Janusfjellet (uppermost siltstone), Oppdalssåta Member, Kimmeridgian (PMO 228.920). Dorsoplanites sp.: (J) External mould of lateral view fragment, DH2 $542.76 \mathrm{~m}$, Slottsmøya Member, middle Volgian (PMO 228.786). (K) External mould of lateral view fragment, DH5R $487.52 \mathrm{~m}$, Slottsmøya Member, middle Volgian (PMO 228.934).

scheme here, awaiting further work on the age of the Myklegardfjellet Bed.

When comparing the individual ammonite finds in the Arctic sections, it is clear that correlation in the Kimmeridgian, Volgian and Ryazanian is considerably easier than in the Bathonian, Callovian and Oxfordian (Callomon, 1959, 1993; Frebold, 1961; Callomon \& Birkelund, 1982; Birkelund \& Callomon, 1985; Århus et al., 1989; Birkenmajer \& Wierzbowski, 1991; Zakharov \& Rogov, 2008; Rogov \& Zakharov, 2009; Rogov, 2010, 2011, 2014, 2016).

Without more ammonite identifications, correlation of the Spitsbergen Callovian/Oxfordian strata with those from Greenland, Siberia and Arctic Canada will remain difficult. Common genera in the Callovian and Oxfordian of northern Siberia, Arctic Canada and Spitsbergen are Kepplerites and Cardioceras (Frebold, 1961; Kopik \& Wierzbowski, 1988; Alifirov et al., 2015). Several species of Amoebites and Amoeboceras can be found in the Kimmeridgian of the Sverdrup Basin (A. rosenkrantzi, A. ravni and A. transitorium) (Frebold, 1961; Wall, 1983), East Greenland (A. subkitchini and A. rasenense) (Callomon \& Birkelund, 1980) and northern Siberia (A. subkitchini and A. bayi) (Rogov, 2016) belonging to the R. cymodoce Zone as in the Agardhfjellet Formation. A. pingueforme is also found above this zone in northern Siberia (Rogov, 2016), as in this study. Boreal ammonites from the middle Volgian, including D. sachsi, D. intermissus, D. maximus, $D$. gracilis and the genus Pavlovia, are frequent occurrences and have been well studied throughout the entire Arctic (Jeletzky, 1966; Callomon \& Birkelund, 1982; Zakharov \&
Rogov, 2008; Rogov \& Zakharov, 2009; Rogov, 2010). The lower and upper Volgian in the Agardhfjellet Formation contain fewer ammonite occurrences. However, the ammonites C. (T.) taimyrensis and Chetaites sp. are found in northern Siberia, Arctic Canada and East Greenland (Jeletzky, 1966; Callomon \& Birkelund, 1982; Rogov \& Zakharov, 2009; Rogov, 2010).

\section{Bivalves}

Buchiid bivalves have been used in the Boreal Upper Jurassic and Lower Cretaceous for biostratigraphical zonation, complementing the established ammonite zones to increase coverage (Table 2). Since in this study we were only able to identify one buchiid to species level, we were not able to compare the results for the entire formation. The presence of Buchia cf. concentrica in the Lardyfjellet Member corresponds with the finds of B. concentrica in East Greenland and Northern Siberia (Surlyk \& Zakharov, 1982; Zakharov, 1987; Rogov \& Zakharov, 2009; Shurygin et al., 2011),

The bivalve diversity in Spitsbergen is low compared with other Arctic areas, such as Milne Land, East Greenland (Fürsich, 1984) and northern Siberia (Zakharov, 1966). When comparing the bivalve assemblages and genera of other Arctic sections to this study, the succession in Milne Land stands out (Fürsich, 1982, 1984). The species richness found in Spitsbergen is significantly lower and the depositional environment of the Agardhfjellet Formation appears to be more distal to the coast than the section in Milne Land, but the trends and presence of genera through the stratigraphy seem to follow a similar sequence (Fürsich, 1982, 1984). As in the Agardhfjellet Formation, the Kap Leslie Formation has a base consisting of coarse-grained sandstone roughly following a fining-upward succession from the Bathonian to the Kimmeridgian (Fig. 10) (Fürsich, 1984; Birkelund \& Callomon, 1985). The Kosmocerasdal Member (Upper Callovian-Upper Oxfordian) is dominated by semiinfaunal/epifaunal bivalves (G. keyserlingii, A. sollae and C. broenlundi) (Fürsich, 1984), although specimen abundances are very low. This fauna is similar to that in the Oppdalen Member. The overlying Aldinger Elv Member (Upper Oxfordian) and Bays Elv Member (Upper Oxfordian-Lower Kimmeridgian) consist of sandstones and specimen abundances in these units are even lower, but still dominated by semi-infaunal/epifaunal assemblages (Fürsich, 1982; Birkelund et al., 1984). These sandstones are interpreted as shallow-water near-shore sandbars wedged in between fine-grained sediment bodies (Fürsich \& Heinberg, 1983). Similar sandstone bodies are not present in Spitsbergen as the location was more distal and laminated black shales were deposited instead (Koevoets et al., 2018). The lack of distinguishable bivalves in the Agardhfjellet Formation prevents detailed comparison with the Milne Land section fauna for this time interval. 


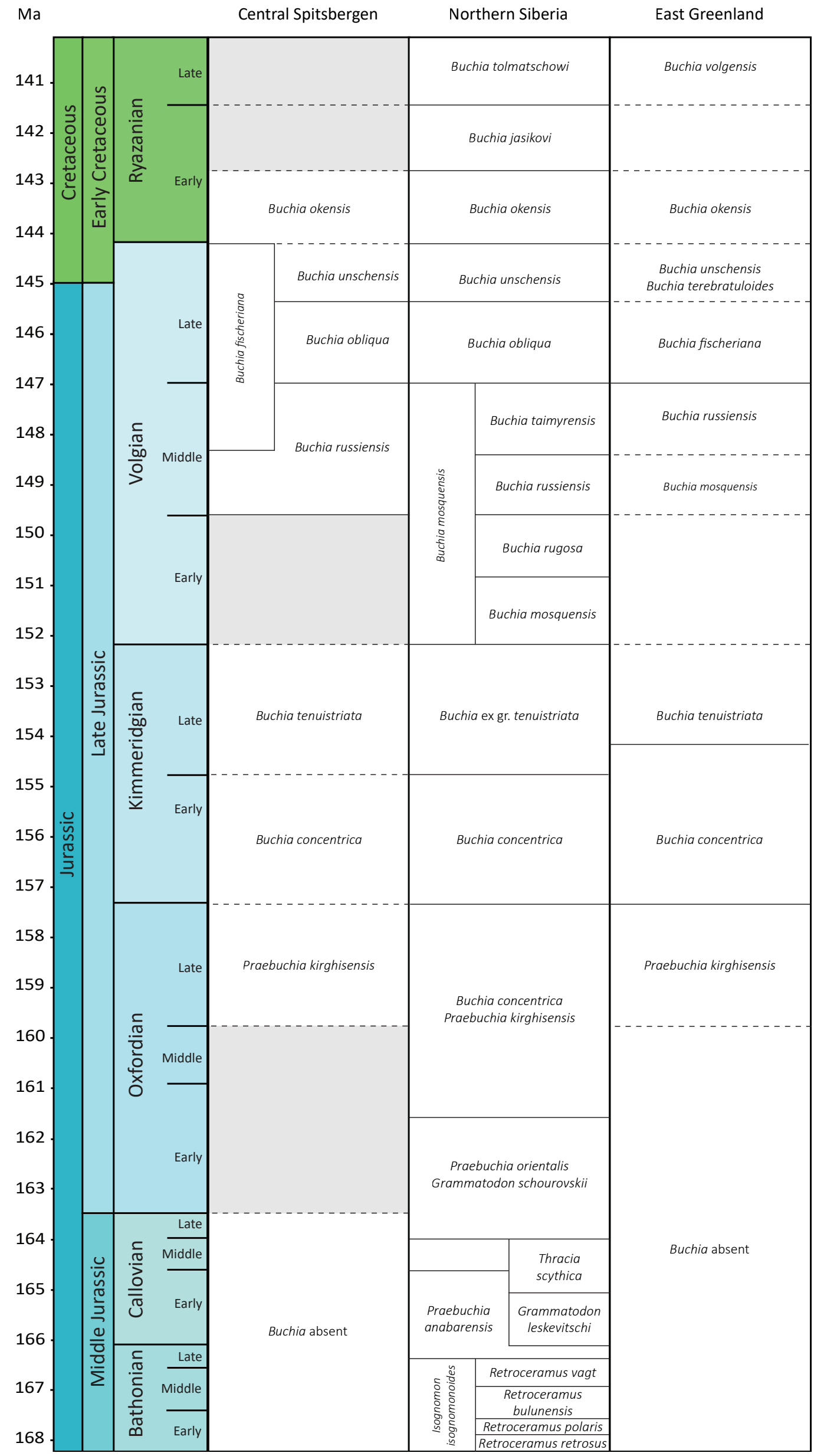


In Milne Land, the Aldinger Elv and Bays Elv Member sandstones are followed by fining-up, outer-shelf siltstones of the epifaunal pectinid bivalve dominated Cardioceraskløft Member (Lower Kimmeridgian) and laminated, black shales of the Gråkløft Member (Kimmeridgian-Lower Volgian). The bivalve fauna of this member was dominated by the Prorokia and Buchia, followed by Astarte, spanning the Kimmeridgian to earliest Volgian age (Birkelund et al., 1984). At this point in the East Greenland section anoxic conditions became widespread (Fürsich, 1984). Black shales containing epifaunal Buchia and infaunal Astarte bivalve faunas are very similar to those of the Lardyfjellet Member, which was also deposited in a dysoxic environment (Koevoets et al., 2018). The major difference in lithology in this interval is the incoming of sandstones of the Oppdalssåta Member in the Upper Kimmeridgian.

In the Volgian Krebsedal, Pernaryggen, Astartedal and Hennigryggen members of East Greenland, the abundance and diversity of bivalves increase drastically (Fürsich, 1982), similar to the trend seen in the Slottsmøya Member in Spitsbergen. As in Spitsbergen, the Milne Land Volgian age siltstones are dominated by infaunal and semi-infaunal bivalves, such as Grammatodon, Pleuromya, Astarte and Hartwellia (Fürsich, 1982). The most commonly found bivalve in Spitsbergen in the Slottsmøya Member is Hartwellia, which is represented by four different species in Milne Land (Fürsich, 1982). Like the Svalbard Slottsmøya Member, the East Greenland Krebsedal, Pernaryggen and Astartedal members consist mainly of shallow shelf siltstones deposited beneath the fair-weather wave base (Fürsich, 1984). The depositional environment and the benthic faunal assemblages of the Volgian stage in East Greenland are interpreted in terms of a shallowing-upward sequence ending in deltaic and lagoonal settings at the end of the middle Volgian in the Hennigryggen Member (Fürsich, 1984). This shallowingupward sequence also seems to be reflected in the lower to middle Volgian of the Slottsmøya Member but in a more distal setting (Koevoets et al., 2018).

To compare the Sverdrup Basin (Canadian Arctic) invertebrate fauna to other Arctic studies more data need to be collected in the future, as previous research mainly focuses on ammonite and Buchia zonation (Frebold, 1961; Jeletzky, 1966; Christie \& McMillan, 1994).

Table 2. Buchiid Zone correlation based on studies of Central Spitsbergen by Surlyk \& Zakharov (1982), Zakharov (1987) and Rogov \& Zakharov (2009), of northern Siberia by Zakharov (1987), (Shurygin et al., 2011), and of East Greenland by Surlyk \& Zakharov (1982), Zakharov (1987) and Rogov \& Zakharov (2009).
The northern Siberian sections on the Nordvik Peninsula do not show the degree of similarity with Spitsbergen seen in the East Greenland faunas. The abundance and diversity of genera in northern Siberia are highest in the Oxfordian and Kimmeridgian (roughly 18 genera) and lowest in the Volgian (4 genera) (Zakharov et al., 2014). The bivalve assemblages were dominated by epifaunal and semi-infaunal genera throughout the Oxfordian to Volgian (Zakharov, 1966) and feeding habits became less diverse toward the end of the Volgian (Zakharov et al., 2014). Deposit feeders were particularly rare in the late Volgian, if present at all. The remaining filter-feeding bivalves were represented by a single genus (Buchia), which is believed to be a result of environmental circumstances, such as deepening of the sea causing low oxygen levels in both bottom waters and substrate (Zakharov et al., 2014). Considering the stratigraphic succession and the difference in bivalve assemblages compared to this study, it appears that the strata in the Nordvik sections were deposited in a marine basin that was isolated from the area in which the Agardhfjellet Formation was deposited, or with very different environmental conditions.

The changes in the less diverse bivalve assemblages in the Agardhfjellet Formation seem to mimic the changes in the more proximal settings of Milne Land, suggesting that these areas were connected oceanographically during the Middle Jurassic to lowermost Cretaceous time period. Assemblages and lithology show an overall transgression and starvation of the basins with widespread undisturbed, laminated, black shale deposits, followed by shallowing-up and more hospitable circumstances causing rapid benthic invertebrate colonisation across the basins (Parker, 1967; Birkelund et al., 1984; Koevoets et al., 2016).

\section{Lingulid brachiopods}

A noteworthy bed is found in the DH2 core at 481-484 $\mathrm{m}$, in the uppermost part of the Slottsmøya Member, where there are abundant specimens of Lingularia sp. (Fig. 8J-L). This lingulate brachiopod genus is also found in hydrocarbon seeps of the member (Holmer \& Nakrem, 2012). A similar bed is present in the lowermost part of the Hennigryggen Member of East Greenland (Fürsich, 1984). The lack of any other benthic invertebrates in these beds signals a significant environmental change. The extant species of Lingula prefer shallow-marine, intertidal, sandy habitats and as a result the fossil relatives were assumed to prefer the same type of environments (Paine, 1970). However, many studies show that fossil species most likely lived in more muddy environments (Paine, 1970; Pickerill et al., 1984; Zabini et al., 2010) and are thus not suitable as an environmental index fossil. Our specimens were found in shales and muddy siltstones, which represent shallow-marine sub-tidal sediments deposited in a regressional stage (Dypvik et al., 1991a, b, 1992; Mørk et al., 1999; Collignon \& Hammer, 2012). 

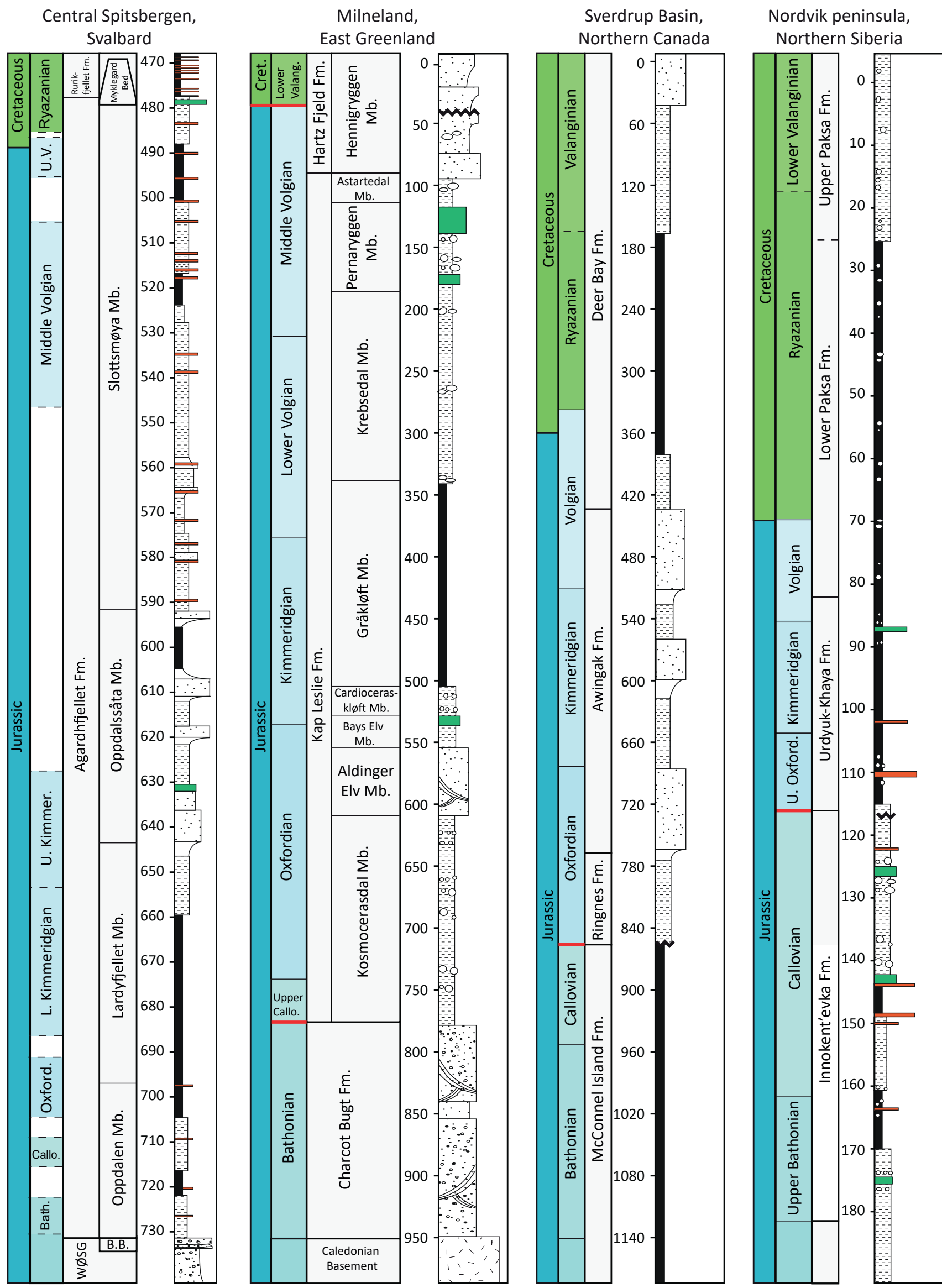

Figure 10. Stratigraphical logs of the Bathonian to Valanginian successions of Spitsbergen (DH2 core based on Koevoets et. al., submitted), Milne Land, East Greenland (based on (Fürsich, 1982, 1984), Sverdrup Basin, Arctic Canada (Embry, 1993) and the Nordvik Peninsula area (composite section), Northern Siberia (Nikitenko et al., 2013, 2015) 


\section{Conclusions}

At outcrop, invertebrate fossils from the shales in the Middle Jurassic to lowermost Cretaceous Agardhfjellet Formation are largely limited to moulds and many are heavily fragmented by frost-wedging in the Arctic environment. In contrast, rock cores drilled as part of the $\mathrm{CO}_{2}$ storage project show that invertebrates in this formation were more abundant and diverse than previously thought.

The ammonite stratigraphy provides a good correlation between this and other Arctic sections. The succession of bivalve assemblages and the accompanying preferred life position and feeding habits fit well with the oxygenation and depositional environments proposed by Koevoets et al. (2018) as a distal response to prograding and retrograding of the coastline.

The Oppdalen Member, with a sparse invertebrate fauna, represents a transition to outer-shelf environments where nektic fauna dominates and benthic fauna consists of rare epifaunal/semi-infaunal bivalve occurrences. The fining-upward successions of the Lardyfjellet and lower Oppdalssåta members are interpreted as a forwardstepping coastline/delta as they shallow from outer-shelf nektic and epifaunal dominated benthic fauna, to the transitional zones where the benthic fauna is dominated by infaunal bivalves as bottom waters become more oxygenated, to relatively proximal sandstones of a distal delta front with extremely low bivalve abundances as a result of the higher energetic environment. The upper Oppdalssåta Member and Slottsmøya Member are interpreted as part of a backstepping coastline/delta sequence, ending in more distal deposits belonging to the transitional zone and eventually outer shelf before shallowing up again in the uppermost Slottsmøya Member. The increased abundance and diversity of the invertebrate fauna and bivalve assemblages dominated by the infaunal Hartwellia sp. for the majority of the Slottsmøya Member is indicative of shallow-shelf conditions.

The sequence of regression and transgression in the Agardhfjellet Formation is similar to the sequences observed in the more proximal East Greenland sections. With similar bivalve genera and assemblage overturns at the same ages, these localities appeared to be connected. In contrast, the northern Siberian Nordvik sections show different bivalve genera, overturning moments and sequence stratigraphy.
Acknowledgements. This study is part of the industry and research council of Norway (the Climit program) sponsored Longyearbyen $\mathrm{CO}_{2} \mathrm{Lab}$ project. In addition, it is part of the "Facies variations of Upper Jurassic source rock interval in the Barents Sea" project funded by ConocoPhillips and Lundin Norway, the ARCEx project (Research Centre for Arctic Petroleum Exploration) funded by the Industry and Research Council of Norway (grant number 228107) and the industrysponsored JuLoCrA project led by the University in Stavanger and UNIS. Thanks to the reviewers, Franz T. Fürsich and Victor Zakharov, for helpful comments on the manuscript. Special thanks to Mikhail Rogov for invaluable help with ammonite identifications.

\section{References}

Alifirov, A.S., Beisel, A.L. \& Meledina, S.V. 2015: The Callovian and Late Jurassic ammonite-based chronostratigraphy of West Siberia: important findings, biostratigraphic review, and basin correlation West Siberia-South England. Swiss Journal of Palaeontology 135, $1-11$.

Allmon, W.D. 1988: Ecology of Recent turritelline gastropods (Prosobranchia, Turritellidae): Current knowledge and paleontological implications. Palaios 3, 259-284. https://doi.org/10.2307/3514657.

Anderson, B.M., Hendy, A., Johnson, E.H. \& Allmon, W.D. 2017: Paleoecology and paleoenvironmental implications of turritelline gastropod-dominated assemblages from the Gatun Formation (Upper Miocene) of Panama. Palaeogeography, Palaeoclimatology, Palaeoecology 470, 132-146.

https://doi.org/10.1016/j.palaeo.2017.01.026.

Birkelund, T. \& Callomon, J.H. 1985: The Kimmeridgian ammonite faunas of Milne Land, central East Greenland. Grønlands Geologiske Undersøgelse 153, 1-56.

Birkelund, T., Callomon, J.H. \& Fürsich, F.T. 1984: The stratigraphy of the Upper Jurassic and Lower Cretaceous sediments of Milne Land, central East Greenland. Bulletin Grønlands Geologiske Undersøgelse 147, 1-56.

Birkenmajer, K. \& Wierzbowski, A. 1991: New Kimmeridgian ammonite fauna from East Spitsbergen and its phyletic significance. Polar Research 9, 169-179. https://doi.org/10.3402/polar.v9i2.6789.

Birkenmajer, K., Pugaczewska, H. \& Wierzbowski, A. 1982: The Janusfjellet Formation (Jurassic-Lower Cretaceous) at Myklegardfjellet, east Spitsbergen. Palaeontologia Polonica 43, 37-46.

Bjærke, T. 1980: Mesozoic palynology of Svalbard V. Dinoflagellates from the Agardhfjellet Member (Middle and Upper Jurassic) in Spitsbergen. Norsk Polarinstitutt Skrifter 172, 145-167.

Braathen, A., Bælum, K., Christiansen, H.H., Dahl, T., Eiken, O., Elvebakk, H., Hansen, F., Hanssen, T.H., Jochmann, M., Johansen, T.A., Johnsen, H., Larsen, L., Lie, T., Mertes, J., Mørk, A., Mørk, M.B., Nemec, W., Olaussen, S., Oye, V., Rød, K., Titlestad, G.O., Tveranger, J. \& Vagle, K. 2012: The Longyearbyen $\mathrm{CO}_{2}$ Lab of Svalbard, Norway-initial assessment of the geological conditions for $\mathrm{CO}_{2}$ sequestration. Norwegian Journal of Geology 92, 353-376.

Callomon, J.H. 1959: The ammonite zones of the Middle Jurassic beds of East Greenland. Geological Magazine 96, 505-512. https://doi.org/10.1017/S0016756800067194.

Callomon, J.H. 1993: The ammonite succession in the Middle Jurassic of East Greenland. Bulletin of the Geological Society of Denmark 40, 83-113.

Callomon, J.H. \& Birkelund, T. 1980: The Jurassic transgression and the mid-late Jurassic succession in Milne Land, central East Greenland. Geological Magazine 117,211-226. https://doi.org/10.1017/S0016756800030442. 
Callomon, J.H. \& Birkelund, T. 1982: The ammonite zones of the Boreal Volgian (Upper Jurassic) in East Greenland. Memoirs of the Canadian Society for Petroleum Geology 8, 349-369.

Christie, R.L. \& McMillan, N.J. 1994: The geology of Melville Island, Arctic Canada. Bulletin of the Geological Survey of Canada 450, 161-193. https://doi.org/10.4095/194013.

Collignon, M. \& Hammer, Ø. 2012: Petrography and sedimentology of the Slottsmøya Member at Janusfjellet, central Spitsbergen. Norwegian Journal of Geology 92, 89-101.

Cox, L.R., Newell, N.D., Boyd, D.W. \& Moore, R.C. 1969: Treatise on Invertebrate Paleontology: Bivalvia. Mollusca 6. Part N. The University of Kansas and The Geological Society of America.

Dalseg, T.S., Nakrem, H.A. \& Smelror, M. 2016: Organic-walled microfossils and palynodebris in cold seep carbonate deposits: The Upper Jurassic-Lower Cretaceous Agardhfjellet Formation on Svalbard (Arctic Norway). Norwegian Journal of Geology 96, 135146. https://doi.org/10.17850/njg96-2-01.

Delsett, L.L., Novis, L.K., Roberts, A.J., Koevoets, M.J., Hammer, Ø., Druckenmiller, P.S. \& Hurum, J.H. 2015: The Slottsmøya marine reptile Lagerstätte: depositional environments, taphonomy and diagenesis. Geological Society of London, Special Publications 434, 165-188. https://doi.org/10.1144/SP434.2.

Delsett, L.L., Roberts, A.J., Druckenmiller, P.S. \& Hurum, J.H. 2017: A new ophthalmosaurid (Ichthyosauria) from Svalbard, Norway, and evolution of the ichthyopterygian pelvic girdle. PloS one 12, e0169971. https://doi.org/10.1371/journal.pone.0169971.

Duff, K.L. 1978: Bivalvia from the English Lower Oxford Clay (Middle Jurassic). Monograph of the Palaeontographical Society, $137 \mathrm{pp}$.

Durska, E. \& Dembicz, K. 2015: Mega-onychites from the Middle and Upper Jurassic of Poland. Neues Jahrbuch für Geologie und Paläontologie - Abhandlungen 276, 315-321. https://doi.org/10.1127/njgpa/2015/0491.

Dypvik, H. 1984: Jurassic and Cretaceous black shales of the Janusfjellet Formation, Svalbard, Norway. Sedimentary Geology 41, 235-248. https://doi.org/10.1016/0037-0738(84)90064-2.

Dypvik, H., Nagy, J., Eikeland, T.A., Backer-Owe, K., Andresen, A., Haremo, P., Bjærke, T., Johansen, H. \& Elverhøi, A. 1991a: The Janusfjellet subgroup (Bathonian to Hauterivian) on central Spitsbergen - a revised lithostratigraphy. Polar Research 9, 21-43. https://doi.org/10.3402/polar.v9i1.6777.

Dypvik, H., Nagy, J., Eikeland, T.A., Backer-Owe, K. \& Johansen, H. 1991b: Depositional conditions of the Bathonian to Hauterivian Janusfjellet Subgroup, Spitsbergen. Sedimentary Geology 72, 55-78. https://doi.org/10.1016/0037-0738(91)90123-U.

Dypvik, H., Nagy, J. \& Krinsley, D.H. 1992: Origin of the Myklegardfjellet bed, a basal Cretaceous marker on Spitsbergen. Polar Research 11,21-31. https://doi.org/10.3402/polar.v11i1.6714.

Embry, A.F. 1993: Transgressive-regressive (T-R) sequence analysis of the Jurassic succession of the Sverdrup Basin, Canadian Arctic Archipelago. Canadian Journal of Earth Sciences 30, 301-320. https://doi.org/10.1139/e93-024.

Ershova, E.S. 1983: Explanatory notes for the biostratigraphical scheme of the Jurassic and Lower Cretaceous deposits of Spitzbergen archipelago. PGO Sevmorgeologia, Leningrad, 88 pp. (in Russian).

Frebold, H. 1961: The Jurassic faunas of the Canadian Arctic. Middle and Upper Jurassic ammonites. Bulletin of the Geological Survey of Canada 74, 1-95. https://doi.org/10.4095/100592.

Fürsich, F.T. 1982: Upper Jurassic bivalves from Milne Land, East Greenland. Grønlands Geologiske Undersøgelse 144, 1-126.

Fürsich, F.T. 1984: Palaeoecology of boreal invertebrate faunas from the Upper Jurassic of Central East Greenland. Palaeogeography, Palaeoclimatology, Palaeoecology 48, 309-364. https://doi.org/10.1016/0031-0182(84)90050-6.

Fürsich, F.T. \& Heinberg, C. 1983: Sedimentology, biostratinomy, and palaeoecology of an Upper Jurassic offshore sand bar complex. Bulletin of the Geological Society of Denmark 32, 67-95.
Gerasimov, P.A. 1955: Index fossils of Mesozoic of the central regions of the European part of the USSR, Part I. Lamellibranchiata, Gastropoda, Scaphopoda and Brachiopoda from the Jurassic deposits. Gosgeoltekhizdat, Moscow, 274 pp. (in Russian).

Ginsburg, L. \& Janvier, P. 1974: Un nouveau gisement à Plésiosaures dans le Jurassique du Spitsbergen (Archipel du Svalbard). ÅrbokNorsk Polarinstitutt 1974, 262-265.

Gradstein, F.M., Ogg, J.G., Schmitz, M. \& Ogg, G. 2012: The geologic time scale 2012. Elsevier, $1176 \mathrm{pp}$.

Hammer, Ø., Nakrem, H.A., Little, C.T.S., Hryniewicz, K., Sandy, M.R., Hurum, J.H., Druckenmiller, P., Knutsen, E.M. \& Høyberget, M. 2011: Hydrocarbon seeps from close to the Jurassic-Cretaceous boundary, Svalbard. Palaeogeography, Palaeoclimatology, Palaeoecology 306, 15-26. https://doi.org/10.1016/j.palaeo.2011.03.019.

Hjálmarsdóttir, H.R., Nakrem, H.A. \& Nagy, J. 2012: Foraminifera from late Jurassic - Early Cretaceous hydrocarbon seep carbonates, central Spitsbergen, Svalbard - Preliminary results. Norwegian Journal of Geology 92, 157-165.

Hodges, P. 2000: The Early Jurassic Bivalvia from the Hettangian and Lower Sinemurian of south-west Britain. Monograph of the Palaeontographical Society of London 154, 1-64.

Holmer, L.E. \& Nakrem, H.A. 2012: The lingulid brachiopod Lingularia from lowermost Cretaceous hydrocarbon seep bodies, Sassenfjorden area, central Spitsbergen, Svalbard. Norwegian Journal of Geology 92, 167-174.

Hryniewicz, K., Little, C.T.S. \& Nakrem, H.A. 2014: Bivalves from the latest Jurassic-earliest Cretaceous hydrocarbon seep carbonates from central Spitsbergen, Svalbard. Zootaxa 3859, 1-66. https://doi.org/10.11646/zootaxa.3859.1.1.

Hryniewicz, K., Hagström, J., Hammer, Ø., Kaim, A., Little, C.T.S. \& Nakrem, H.A. 2015: Late Jurassic-Early Cretaceous hydrocarbon seep boulders from Novaya Zemlya and their faunas. Palaeogeography, Palaeoclimatology, Palaeoecology 436, 231-244. https://doi.org/10.1016/j.palaeo.2015.06.036.

Hurum, J.H., Nakrem, H.A., Hammer, Ø., Knutsen, E.M., Druckenmiller, P.S., Hryniewicz, K. \& Novis, L.K. 2012: An Arctic Lagerstätte - the Slottsmøya Member of the Agardhfjellet Formation (Upper Jurassic-Lower Cretaceous) of Spitsbergen. Norwegian Journal of Geology 92, 55-64.

Imlay, R.W. 1953: Callovian (Jurassic) ammonites from the United States and Alaska. Part 1. Western Interior United States. Geological Survey Professional Paper 249-A, 1-39.

Jeletzky, J.A. 1966: Upper Volgian (latest Jurassic) ammonites and buchias of Arctic Canada. Bulletin of the Geological Survey of Canada 128, 1-51. https://doi.org/10.4095/101473.

Kędzierski, M., Uchman, A., Sawlowicz, Z. \& Briguglio, A. 2015: Fossilized bioelectric wire-the trace fossil Trichichnus. Biogeosciences 12, 2301-2309. https://doi.org/10.5194/bg-12-2301-2015.

Kelly, S.R.A. 1984: Bivalvia of the Spilsby Sandstone and Sandringham Sands (Late Jurassic-Early Cretaceous) of eastern England. Monograph of the Palaeontographical Society of London 137, 1-94.

Kenig, F., Hudson, J.D., Damste, J.S.S. \& Popp, B.N. 2004: Intermittent euxinia: reconciliation of a Jurassic black shale with its biofacies. Geology 32, 421-424. https://doi.org/10.1130/G20356.1.

Knutsen, E.M., Druckenmiller, P.S. \& Hurum, J.H. 2012: Redescription and taxonomic clarification of "Tricleidus" svalbardensis based on new material from the Agardhfjellet Formation (Middle Volgian). Norwegian Journal of Geology 92, 175-186.

Koevoets, M.J., Abay, T.B., Hammer, Ø. \& Olaussen, S. 2016: Highresolution organic carbon-isotope stratigraphy of the Middle Jurassic-Lower Cretaceous Agardhfjellet Formation of central Spitsbergen, Svalbard. Palaeogeography, Palaeoclimatology, Palaeoecology 449, 266-274. https://doi.org/10.1016/j.palaeo.2016.02.029. 
Koevoets, M.J., Hammer, Ø., Olaussen, S., Senger, K. \& Smelror, M. 2018: Integrating subsurface and outcrop data of the Middle Jurassic to Lower Cretaceous Agardhfjellet Formation in central Spitsbergen. Norwegian Journal of Geology 98, 1-34.

Kopik, J. \& Wierzbowski, A. 1988: Ammonites and stratigraphy of the Bathonian and Callovian at Janusfjellet and Wimanfjellet, Sassenfjorden, Spitsbergen, Norway. Acta Palaeontologica Polonica 33, 145-168.

Krymholts, G.Y. \& Mesezhnikov, M.S. 1988: The Jurassic ammonite zones of the Soviet Union. Geological Society of America Special Papers 223, 1-3. https://doi.org/10.1130/SPE223-p1.

Mesezhnikov, M.S. 1972: A New Arctic Genus of Middle Volgian Dorsoplanites Problems of the paleozoogeography of the Siberian Mesozoic. Transactions of the Institute of Geology and Geophysics: Siberian Branch of the Academy of Sciences USSR 111, 119-131 (in Russian).

Mesezhnikov, M.S. 1984: Kimmeridgian and Volgian Stages in the Northern Soviet Union. Nedra, Leningrad, 224 pp. (in Russian).

Milashevich, K.O. 1881: Geological investigations held during the summer of the year 1878 in the south-west part of the Kostroma Government. Extracts from materials for the Geology of Russia X, 131-198 (in Russian).

Mitta, V., Kostyleva, V., Dzyuba, O., Glinskikh, L., Shurygin, B., Seltzer, V., Ivanov, A. \& Urman, O. 2014: Biostratigraphy and sedimentary settings of the Upper Bajocian - Lower Bathonian in the vicinity of Saratov (Central Russia). Neues Jahrbuch für Geologie und Paläontologie Abhandlungen 271, 95-121. https://doi.org/10.1127/0077-7749/2014/0380.

Mørk, A., Dallmann, W.K., Dypvik, H., Johannessen, E.P., Larssen, G.B., Nagy, J., Nøttevedt, A., Olaussen, S., Pčelina, T.M. \& Worsley, D. 1999: Lithostratigraphic lexicon of Svalbard. Review and recommendationsfor nomenclature use. Upper Palaeozoic to Quaternary bedrock. Norsk Polarinstitutt Tromsø, Norway, 127-214 pp.

Nagy, J. \& Basov, V.A. 1998: Revised foraminiferal taxa and biostratigraphy of Bathonian to Ryazanian deposits in Spitsbergen. Micropaleontology 44,217-255. https://doi.org/10.2307/1486047.

Nagy, J., Löfaldli, M., Bäckström, S.A. \& Johansen, H. 1990: Agglutinated foraminiferal stratigraphy of Middle Jurassic to basal Cretaceous shales, Central Spitsbergen. In Hemleben, C., Kaminski, M.A., Kuhnt, W. \& Scott, D.B. (eds.): Paleoecology, Biostratigraphy, Paleoceanography and Taxonomy of Agglutinated Foraminifera, Kluwer Academic Publishing, Chichester, pp. 969-1015. https://doi.org/10.1007/978-94-011-3350-0_38.

Nagy, J., Reolid, M. \& Rodriguez-Tovar, F.J. 2009: Foraminiferal morphogroups in dysoxic shelf deposits from the Jurassic of Spitsbergen. Polar Research 28, 214-221. https://doi.org/10.1111/j.1751-8369.2009.00112.x.

Nakrem, H.A. \& Kiessling, W. 2012: Late Jurassic (Volgian) radiolarians from central Spitsbergen-a preliminary study. Norwegian Journal of Geology 92, 149-155.

Nikitenko, B.L., Shurygin, B.N., Knyazev, V.G., Meledina, S.V., Dzyuba, O.S., Lebedeva, N.K., Peshchevitskaya, E.B., Glinskikh, L.A., Goryacheva, A.A. \& Khafaeva, S.N. 2013: Jurassic and Cretaceous stratigraphy of the Anabar area (Arctic Siberia, Laptev Sea coast) and the Boreal zonal standard. Russian Geology and Geophysics 54, 808-837. https://doi.org/10.1016/j.rgg.2013.07.005.

Nikitenko, B.L., Knyazev, V.G., Peshchevitskaya, E.B., Glinskikh, L.A., Kutygin, R.V. \& Alifirov, A.S. 2015: High-resolution stratigraphy of the Upper Jurassic section (Laptev Sea coast). Russian Geology and Geophysics 56, 663-685. https://doi.org/10.1016/j.rgg.2015.03.014.

Ogata, K., Senger, K., Braathen, A., Tveranger, J. \& Olaussen, S. 2014: The importance of natural fractures in a tight reservoir for potential $\mathrm{CO}_{2}$ storage: a case study of the upper Triassic-middle Jurassic Kapp Toscana Group (Spitsbergen, Arctic Norway). Geological Society of London, Special Publications 374, 395-415. https://doi.org/10.1144/SP374.9.
Paine, R.T. 1970: The sediment occupied by recent lingulid brachiopods and some paleoecological implications. Palaeogeography, Palaeoclimatology, Palaeoecology 7, 21-31. https://doi.org/10.1016/0031-0182(70)90023-4.

Parker, J.R. 1967: The Jurassic and Cretaceous sequence in Spitsbergen. Geological Magazine 104, 487-505. https://doi.org/10.1017/S0016756800049220.

Pauly, S., Mutterlose, J. \& Alsen, P. 2012: Lower Cretaceous (upper Ryazanian-Hauterivian) chronostratigraphy of high latitudes (north-east Greenland). Cretaceous Research 34, 308-326. https://doi.org/10.1016/j.cretres.2011.11.011.

Pickerill, R.K., Harland, T.L. \& Fillion, D. 1984: In situ lingulids from deep-water carbonates of the Middle Ordovician Table Head Group of Newfoundland and the Trenton Group of Quebec. Canadian Journal of Earth Sciences 21, 194-199. https://doi.org/10.1139/e84-021.

Roberts, A.J., Druckenmiller, P.S., Sætre, G.P. \& Hurum, J.H. 2014: A new Upper Jurassic ophthalmosaurid ichthyosaur from the Slottsmøya Member, Agardhfjellet Formation of central Spitsbergen. PloS one 9, e103152. https://doi.org/10.1371/journal.pone.0103152.

Roberts, A.J., Druckenmiller, P.S., Delsett, L.L. \& Hurum, J.H. 2017: Osteology and relationships of Colymbosaurus Seeley, 1874, based on new material of C. svalbardensis from the Slottsmøya Member, Agardhfjellet Formation of central Spitsbergen. Journal of Vertebrate Paleontology 37, e1278381. https://doi.org/10.1080/02724634.2017.1278381.

Rogov, M.A. 2010: New data on ammonites and stratigraphy of the Volgian stage in Spitzbergen. Stratigraphy and Geological Correlation 18, 505-531. https://doi.org/10.1134/S0869593810050047.

Rogov, M.A. 2014: An infrazonal ammonite biostratigraphy for the Kimmeridgian of Spitsbergen. Norwegian Petroleum Directorate Bulletin 11, 153-165.

Rogov, M.A. 2016: New zonal and infrazonal scales for the Kimmeridgian in Western Siberia based on cardioceratid ammonites. Stratigraphy and Geological Correlation 24, 503-526. https://doi.org/10.1134/S0869593816050051.

Rogov, M.A, 2018: High-resolution ammonite-based biostratigraphy of the Adventdalen Group (Middle Jurassic-Lower Cretaceous) of Spitsbergen. Geophysical Research Abstracts 20, EGU General Assembly 2018, EGU2018-17980.

Rogov, M.A. \& Zakharov, V.A. 2009: Ammonite- and bivalve-based biostratigraphy and Panboreal correlation of the Volgian Stage. Science in China, Series D: Earth Sciences 52, 1890-1909. https://doi.org/10.1007/s11430-009-0182-0.

Rogov, M.A., Zakharov, V.A. \& Ershova, V.B. 2011: Detailed stratigraphy of the Jurassic-Cretaceous boundary beds of the Lena River lower reached based on ammonites and Buchiids. Stratigraphy and Geological Correlation 19, 641-662. https://doi.org/10.1134/S0869593811060050.

Rousseau, J. \& Nakrem, H.A. 2012: An Upper Jurassic Boreal echinoderm Lagerstätte from Janusfjellet, central Spitsbergen. Norwegian Journal of Geology 92, 133-161.

Sand, G., Braathen, A. \& Olaussen, S. 2014: Longyearbyen $\mathrm{CO}_{2} \mathrm{Lab}$ tales of research and education. Norwegian Journal of Geology 94, 77-82.

Sandy, M.R., Hryniewicz, K., Hammer, Ø., Nakrem, H.A. \& Little, C.T.S. 2014: Brachiopods from Late Jurassic-Early Cretaceous hydrocarbon seep deposits, central Spitsbergen, Svalbard. Zootaxa 3884, 501-532. https://doi.org/10.11646/zootaxa.3884.6.1.

Shurygin, B.N., Nikitenko, B.L., Meledina, S.V., Dzyuba, O.S. \& Knyazev, V.G. 2011: Comprehensive zonal subdivisions of Siberian Jurassic and their significance for Circum-Arctic correlations. Russian Geology and Geophysics 52, 825-844. https://doi.org/10.1016/j.rgg.2011.07.007. 
Stanley, S.M. 1970: Relation of shell form to life habits of the Bivalvia (Mollusca). Geological Society of America Memoir 125, 1-296. https://doi.org/10.1130/MEM125-p1.

Surlyk, F. 1991: Sequence stratigraphy of the Jurassic-lowermost Cretaceous of east Greenland. American Association of Petroleum Geologists Bulletin 75, 1468-1488.

Surlyk, F. \& Zakharov, V.A. 1982: Buchiid bivalves from the upper Jurassic and lower Cretaceous of East Greenland. Palaeontology 25, 727-753.

Wall, J.H. 1983: Jurassic and Cretaceous foraminiferal biostratigraphy in the eastern Sverdrup Basin, Canadian Arctic Archipelago. Bulletin of Canadian Petroleum Geology 31, 246-281.

Wierzbowski, A. 1989: Ammonites and stratigraphy of the Kimmeridgian at Wimanfjellet, Sassenfjorden, Spitsbergen. Acta Palaeontologica Polonica 34, 355-378.

Wierzbowski, A., Hryniewicz, K., Hammer, Ø., Nakrem, H.A. \& Little, C.T.S. 2011: Ammonites from hydrocarbon seep carbonate bodies from the uppermost Jurassic - lowermost Cretaceous of Spitsbergen and their biostratigraphical importance. Neues Jahrbuch für Geologie und Paläontologie - Abhandlungen 262, 267288. https://doi.org/10.1127/0077-7749/2011/0198.

Wignall, P.B. 1990: Benthic palaeoecology of the late Jurassic Kimmeridge Clay of England. Special Papers in Palaeontology 43, $1-74$.

Zabini, C., Bosetti, E.P. \& Holz, M. 2010: Taphonomy and taphofacies analysis of lingulid brachiopods from Devonian sequences of the Paraná Basin, Brazil. Palaeogeography, Palaeoclimatology, Palaeoecology 292, 44-56. https://doi.org/10.1016/j.palaeo.2010.03.025.

Zakharov, V.A. 1966: Late Jurassic and Early Cretaceous bivalves of the North of Siberia and their paleoecology. Order Anisomyaria. Problems of the paleozoogeography of the Siberian Mesozoic. Transactions of the Institute of Geology and Geophysics: Siberian Branch of the Academy of Sciences USSR 113, 1-189 (in Russian).

Zakharov, V.A. 1981: Buchiids and biostratigraphy of the boreal Upper Jurassic and Neocomian. Transactions of the Academy of Sciences USSR, Siberian Branch, Institute for Geology and Geophysics 458, 270 pp. (in Russian).

Zakharov, V.A. 1987: The bivalve Buchia and the Jurassic-Cretaceous boundary in the Boreal province. Cretaceous Research 8, 141-153. https://doi.org/10.1016/0195-6671(87)90018-8.

Zakharov, V.A. \& Rogov, M.A. 2008: The Upper Volgian Substage in northeast Siberia (Nordvik Peninsula) and its Panboreal correlation based on ammonites. Stratigraphy and Geological Correlation 16, 423-436. https://doi.org/10.1134/S0869593808040059.

Zakharov, V.A., Rogov, M.A., Dzyuba, O.S., Žák, K., Košt’ák, M., Pruner, P., Skupien, P., Chadima, M., Mazuch, M. \& Nikitenko, B.L. 2014: Palaeoenvironments and palaeoceanography changes across the Jurassic/Cretaceous boundary in the Arctic realm: case study of the Nordvik section (north Siberia, Russia). Polar Research 33, 19714. https://doi.org/10.3402/polar.v33.19714.

Zell, P. \& Stinnesbeck, W. 2015: Kimmeridgian (Late Jurassic) coldwater idoceratids (Ammonoidea) from southern Coahuila, northeastern Mexico, associated with Boreal bivalves and belemnites. Revista Mexicana de Ciencias Geológicas 32, 11-20.

Århus, N. 1988: Palynostratigraphy of some Bathonian-Hauterivian sections in the Arctics, with emphasis on the Janusfjellet Formation type section, Spitsbergen. Unpublished IKU report, 1-139.

Århus, N., Birkelund, T. \& Smelror, M. 1989: Biostratigraphy of some Callovian and Oxfordian cores off Vega, Helgeland, Norway. Norwegian Journal of Geology 69, 39-56. 